\title{
Biodiversity and trophic ecology of hydrothermal vent fauna associated with tubeworm assemblages on the Juan de Fuca Ridge
}

\author{
Yann Lelièvre ${ }^{1,2}$, Jozée Sarrazin ${ }^{1}$, Julien Marticorena ${ }^{1}$, Gauthier Schaal ${ }^{3}$, Thomas Day ${ }^{1}$, Pierre Legendre $^{2}$, \\ Stéphane Hourdez ${ }^{4,5}$, and Marjolaine Matabos ${ }^{1}$ \\ ${ }^{1}$ Ifremer, Centre de Bretagne, REM/EEP, Laboratoire Environnement Profond, 29280 Plouzané, France \\ ${ }^{2}$ Département de sciences biologiques, Université de Montréal, C.P. 6128, succursale Centre-ville, \\ Montréal, Québec, H3C 3J7, Canada \\ ${ }^{3}$ Laboratoire des Sciences de l'Environnement Marin (LEMAR), UMR 65399 CNRS/UBO/IRD/Ifremer, \\ BP 70, 29280, Plouzané, France \\ ${ }^{4}$ Sorbonne Université, UMR7144, Station Biologique de Roscoff, 29680 Roscoff, France \\ ${ }^{5}$ CNRS, UMR7144, Station Biologique de Roscoff, 29680 Roscoff, France
}

Correspondence: Yann Lelièvre (yann.lelievre10@gmail.com)

Received: 3 October 2017 - Discussion started: 12 October 2017

Revised: 29 March 2018 - Accepted: 7 April 2018 - Published: 4 May 2018

\begin{abstract}
Hydrothermal vent sites along the Juan de Fuca Ridge in the north-east Pacific host dense populations of Ridgeia piscesae tubeworms that promote habitat heterogeneity and local diversity. A detailed description of the biodiversity and community structure is needed to help understand the ecological processes that underlie the distribution and dynamics of deep-sea vent communities. Here, we assessed the composition, abundance, diversity and trophic structure of six tubeworm samples, corresponding to different successional stages, collected on the Grotto hydrothermal edifice (Main Endeavour Field, Juan de Fuca Ridge) at $2196 \mathrm{~m}$ depth. Including $R$. piscesae, a total of 36 macrofaunal taxa were identified to the species level. Although polychaetes made up the most diverse taxon, faunal densities were dominated by gastropods. Most tubeworm aggregations were numerically dominated by the gastropods Lepetodrilus fucensis and Depressigyra globulus and polychaete Amphisamytha carldarei. The highest diversities were found in tubeworm aggregations characterised by the longest tubes $(18.5 \pm 3.3 \mathrm{~cm})$. The high biomass of grazers and high resource partitioning at a small scale illustrates the importance of the diversity of free-living microbial communities in the maintenance of food webs. Although symbiont-bearing invertebrates $R$. piscesae represented a large part of the total biomass, the low number of specialised predators on this potential food source suggests that its primary role lies in
\end{abstract}

community structuring. Vent food webs did not appear to be organised through predator-prey relationships. For example, although trophic structure complexity increased with ecological successional stages, showing a higher number of predators in the last stages, the food web structure itself did not change across assemblages. We suggest that environmental gradients provided by the biogenic structure of tubeworm bushes generate a multitude of ecological niches and contribute to the partitioning of nutritional resources, releasing communities from competition pressure for resources and thus allowing species to coexist.

\section{Introduction}

Deep-sea hydrothermal vents occur along mid-ocean ridges and back-arc spreading centres, which are characterised by strong volcanic and tectonic activity. The resulting hydrothermal fluid fosters dense communities of highly specialised fauna that colonise the steep physical and chemical gradients created by the mixing of hot vent fluids with cold seawater. These communities are distributed according to species' physiological tolerance (Childress and Fisher, 1992; Luther et al., 2001), resource availability (De Busserolles et al., 2009; Levesque et al., 2003) and biotic interactions (Lenihan et al., 2008; Micheli et al., 2002; 
Mullineaux et al., 2000, 2003). Although the fauna are highly dissimilar between oceanic basins (Bachraty et al., 2009; Moalic et al., 2011), hydrothermal communities throughout the world share some ecological similarities including a food web based on chemosynthesis (Childress and Fisher, 1992), low species diversity compared with adjacent deep-sea and coastal benthic communities (Van Dover and Trask, 2000; Tunnicliffe, 1991), high levels of endemism (Ramirez-Llodra et al., 2007), and elevated biomass associated with the presence of large invertebrate species.

The high spatial heterogeneity of environmental conditions in vent ecosystems is amplified by stochastic and periodic temporal variation in hydrothermal activity, influencing the composition (Sarrazin et al., 1999), structure (Marcus et al., 2009; Sarrazin et al., 1997; Tsurumi and Tunnicliffe, 2001) and dynamics (Lelièvre et al., 2017; Nedoncelle et al., 2013, 2015; Sarrazin et al., 2014) of faunal communities. In addition, the complexity of vent habitats is increased by engineer species, whose presence strongly contributes to the modification of the physical (temperature, hydrodynamics processes) and chemical (hydrogen sulfide, methane, oxygen, metals and other reduced chemicals) properties of the environment either by creating three-dimensional biogenic structures (autogenic species) or through their biological activity (allogeneic species) (Jones et al., 1994, 1997). Habitat provisioning and modification by engineer species increases the number of potential ecological niches and, consequently, influences species distribution and contributes to an increase in local diversity (Dreyer et al., 2005; Govenar and Fisher, 2007; Urcuyo et al., 2003). Engineer species promote local diversity through various ecological mechanisms (Bergquist et al., 2003), providing a secondary substratum for colonisation, a refuge from predation and unfavourable abiotic conditions, and important food sources that enhance the development of macro- and meiofaunal communities (Dreyer et al., 2005; Galkin and Goroslavskaya, 2010; Gollner et al., 2006; Govenar et al., 2005, 2002; Govenar and Fisher, 2007; Turnipseed et al., 2003; Zekely et al., 2006).

Hydrothermal vent food webs are mainly based on local microbial chemosynthesis (Childress and Fisher, 1992), performed by free-living or/and symbiotic chemoautotrophic microorganisms that utilise the chemical energy released by the oxidation of reduced chemicals species $\left(\mathrm{H}_{2}, \mathrm{H}_{2} \mathrm{~S}, \mathrm{CH}_{4}\right)$ present in the hydrothermal fluids (Childress and Fisher, 1992). Several electron donors (e.g. $\mathrm{H}_{2}, \mathrm{H}_{2} \mathrm{~S}, \mathrm{CH}_{4}, \mathrm{NH}_{4}^{+}$) and electron acceptors (e.g. $\mathrm{O}_{2}, \mathrm{NO}_{3}^{-}, \mathrm{SO}_{4}^{2-}$ ) can be used by these microorganisms as energy sources, converting inorganic carbon (e.g. $\mathrm{CO}_{2}$ ) into simple carbohydrates (Fisher et al., 2007). Chemosynthetic primary production is exported to the upper trophic levels through direct ingestion (primary consumers) or through the presence of intra- or extracellular symbiosis. Upper trophic levels (secondary consumers) are represented by local predators and scavengers feeding on primary consumers and by abyssal species attracted by the pro- fusion of food. Stable isotopes analysis is an important and efficient tool in studying trophic ecology and offers many advantages over traditional methods (behavioural observations, stomach content analyses), providing the time-integrated overview of an animal's diet over a long timescale. Nevertheless, the physiology of marine invertebrates is poorly documented, resulting in a lack of precision on the turnover rate of an organism's tissue and therefore, the rate at which a consumer integrates the isotopic signal, leading to an uncertainty about trophic-step fractionation (isotopic enrichment between preys and predators). Moreover, although trophic inferences using stable isotopes require the characterisation of basal sources, this remains difficult in the hydrothermal environment due to technological sampling constraints. Despite this, the emergence of isotopic methods has opened new perspectives in the understanding of food web functioning and the organisation of species diversity within these ecosystems around the globe (Bergquist et al., 2007; De Busserolles et al., 2009; Van Dover, 2002; Erickson et al., 2009; Gaudron et al., 2012; Levesque et al., 2006; Levin et al., 2009; Limén et al., 2007; Portail et al., 2016; Soto, 2009; Sweetman et al., 2013). The carbon isotope composition $\left(\delta^{13} \mathrm{C}\right)$ is an indicator of the food assimilated and remains relatively constant during trophic transfers $( \pm 1 \%$ ). The kinetics of enzymes involved in the biosynthetic pathways of autotrophic organisms influence the carbon isotope ratio $\left({ }^{13} \mathrm{C} /{ }^{12} \mathrm{C}\right)$, allowing the discrimination between the sources fuelling the community (Conway et al., 1994; Van Dover and Fry, 1989). Nitrogen isotope composition $\left(\delta^{15} \mathrm{~N}\right)$ provides information on trophic levels and becomes enriched in heavy isotopes at an average rate of $\pm 3.4 \%$ at each trophic level (Michener and Lajtha, 2008). At the community scale, $\delta^{13} \mathrm{C}$ and $\delta^{15} \mathrm{~N}$ signatures of all species in the ecosystem are used to retrace carbon and nitrogen fluxes along the trophic chain and, therefore, to reconstitute the food web (Levin and Michener, 2002). Despite the relatively low diversity of vent communities, ample evidence suggests that hydrothermal food web structure is complex (Bergquist et al., 2007; Portail et al., 2016), including many trophic guilds (Bergquist et al., 2007; De Busserolles et al., 2009) and multiple sources of primary production (Van Dover and Fry, 1994). The carbon signature $\left({ }^{13} \mathrm{C}\right)$ of primary producers differs according to their carbon fixation pathways that differentially fractionate inorganic carbon sources. Despite the fact that the nitrogen signature $\left(\delta^{15} \mathrm{~N}\right)$ does not discriminate between primary producers, the variability of $\delta^{15} \mathrm{~N}$ signatures can be associated with their origins and also with local biogeochemical processes (Bourbonnais et al., 2012; Portail et al., 2016). Moreover, due to its degradation in the water column, photosynthesisderived organic matter is characterised by high $\delta^{15} \mathrm{~N}$ values in comparison with local vent microbial producers, which are associated with low or negative values characteristic of local inorganic nitrogen sources (Conway et al., 1994).

Active hydrothermal vents on the Juan de Fuca Ridge (north-east Pacific) are colonised by populations of the si- 


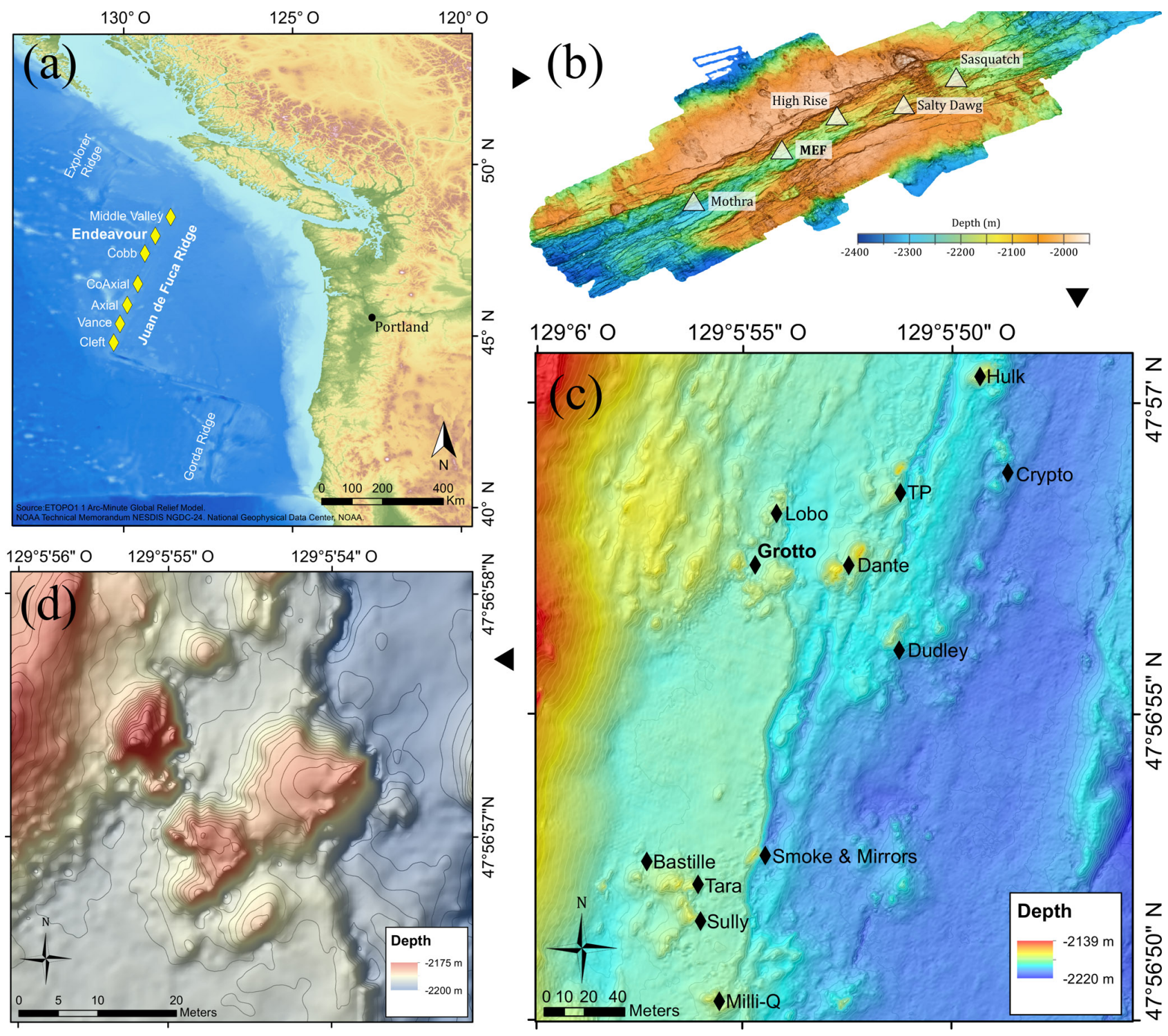

Figure 1. (a) Location of the Juan de Fuca Ridge system and the seven segments (yellow diamonds). (b) High-resolution bathymetric map of the Endeavour Segment, with the locations of the five main active vent fields (white triangles). (c) Location map of the Main Endeavour vent field indicating the positions of hydrothermal vent edifices (black diamonds). (d) Bathymetric map of the Grotto active hydrothermal edifice $\left(47^{\circ} 56.958^{\prime} \mathrm{N}, 129^{\circ} 5.899^{\prime} \mathrm{W}\right)$. The $10 \mathrm{~m}$ high sulfide structure is located in the Main Endeavour vent field.

boglinid polychaete Ridgeia piscesae forming dense faunal assemblages in areas of high to low fluid flux activity (Southward et al., 1995). Diverse heterotrophic faunal species inhabit these tubeworm bushes, with a dominance of polychaete and gastropod species (Bergquist et al., 2007; Govenar et al., 2002; Marcus et al., 2009; Tsurumi and Tunnicliffe, 2001, 2003). To date, few studies have described the communities associated with the $R$. piscesae tubeworm assemblages of the Main Endeavour vent field, either in terms of diversity (Bergquist et al., 2007; Sarrazin et al., 1997) or trophic ecology (Bergquist et al., 2007). Six distinct faunal assemblages exhibiting patchy distributions have been iden- tified on the Smoke and Mirrors hydrothermal edifice, and appear to represent different successional stages (Sarrazin et al., 1997). Since 2011, a camera installed on the Ocean Networks Canada cabled observatory has been recording highresolution imagery of a $R$. piscesae tubeworm assemblage and its associated fauna on the active Grotto hydrothermal edifice (Main Endeavour, Juan de Fuca Ridge). The processing of this data provided new insights into the influence of astronomic and atmospheric forcing on vent faunal dynamics (Cuvelier et al., 2014; Lelièvre et al., 2017), but thorough knowledge of the faunal communities observed by the camera is still needed to understand and interpret the tem- 
poral patterns and their underlying mechanisms. However, although video imagery is useful for investigating the spatial distribution of communities (Cuvelier et al., 2011; Sarrazin et al., 1997), species behaviour (Grelon et al., 2006; Matabos et al., 2015) and temporal dynamics of a subset of species $(\mathrm{Cu}-$ velier et al., 2014; Lelièvre et al., 2017), direct sampling is an essential and complementary approach for determining overall faunal composition, abundance and species diversity and assess functioning (Cuvelier et al., 2012). In this context, the objectives of the present study were (i) to identify the composition and structure of three faunal assemblages associated with $R$. piscesae tubeworm bushes on the Grotto hydrothermal edifice, specifically with respect to density, biomass and species diversity, (ii) to characterise the trophic structure of these biological communities, and (iii) to assess how diversity and trophic relationships vary over different successional stages.

\section{Materials and methods}

\subsection{Geological setting}

The Juan de Fuca Ridge (JdFR) (Fig. 1a) is an intermediate spreading-rate ridge between the Pacific and Juan de Fuca plates in the north-east Pacific Ocean. The Endeavour Segment $\left(47^{\circ} 57^{\prime} \mathrm{N}, 129^{\circ} 06^{\prime} \mathrm{W}\right)$ (Fig. 1b) constitutes a $\sim 90 \mathrm{~km}$ long section of the JdFR, bounded to the north by the Middle Valley and to the south by the Cobb Segment. It is characterised by a $500-1000 \mathrm{~m}$ wide axial valley whose walls reach up to $200 \mathrm{~m}$ in height (Delaney et al., 1992). The five major vent fields - Sasquatch, Salty Dawg, High Rise, Main Endeavour Field (MEF) and Mothra - found along the Endeavour axial valley are spaced regularly, about $2-3 \mathrm{~km}$ apart.

The MEF (Fig. 1c) is the most active of the five hydrothermal fields, with the presence of high-temperature $\left(370-390^{\circ} \mathrm{C}\right)$, actively venting sulfide edifices and diffuse low-temperature $\left(10-25^{\circ} \mathrm{C}\right)$ venting areas (Delaney et al., 1992; Kelley et al., 2012). This vent field is the world's first hydrothermal marine protected area (Devey et al., 2007; Tunnicliffe and Thomson, 1999) and was selected as a target site for the deep-sea cabled observatory Ocean Networks Canada, providing unprecedented opportunities to better understand vent ecology. Within the MEF, Grotto $\left(47^{\circ} 56.958^{\prime} \mathrm{N}, 129^{\circ} 5.899^{\prime} \mathrm{W}\right.$; Fig. 1d) is an active hydrothermal sulfide vent cluster $(15 \mathrm{~m}$ long by $10 \mathrm{~m}$ wide by $10 \mathrm{~m}$ high) located at $2196 \mathrm{~m}$ depth that forms an open cove to the north. This edifice is characterised by high short-term variation in heat flux but is stable across years ( $\mathrm{Xu}$ et al., 2014). Like many other MEF hydrothermal edifices, the site is largely colonised by dense assemblages of Ridgeia piscesae (Polychaeta, Siboglinidae) with their associated fauna (Bergquist et al., 2007; Govenar et al., 2002; Sarrazin et al., 1997; Urcuyo et al., 2007).

\subsection{Faunal assemblage sampling}

Sampling took place during the ONC (Ocean Networks Canada) oceanographic cruises Wiring the Abyss 2015 and 2016 from 25 August to 14 September 2015 on the R/V Thomas G. Thompson, and from 10 May to 29 May 2016 on the E/V Nautilus, respectively. Using the remotely operated vehicles (ROVs) Jason and Hercules, three samples of Ridgeia piscesae tubeworms and their associated fauna were sampled each year at different locations on the Grotto hydrothermal edifice ( $n=6$; S1 to S6, Fig. 2). These samples corresponded to three distinct assemblages (assemblage III, assemblage IV and assemblage V low flow) according to Sarrazin et al. (1997). For each sample, a checkerboard of $7 \times 7 \mathrm{~mm}$ squares was first placed on each tubeworm sample to estimate the surface area. Then, the first suction sample was taken to recover the mobile fauna, followed by collection of tubeworms and their associated fauna, which were placed in a BioBox using the ROV's mechanical arm. A final suction sample on the bare surface was performed to recover the remaining fauna. The final sampled surface area was filmed with the ROV camera to estimate its surface using imagery (see protocol in Sarrazin et al., 1997).

\subsection{Sample processing}

\subsubsection{Sample processing and identification}

On board, all faunal samples were washed over stacked sieves ( 250 and $63 \mu \mathrm{m}$ mesh sizes). Macrofaunal specimens $(>250 \mu \mathrm{m})$ were preserved in $96 \%$ ethanol and meiofauna $(250 \mu \mathrm{m}>x>63 \mu \mathrm{m})$ in $10 \%$ seawater formalin. In the laboratory, bushes of Ridgeia piscesae were thoroughly disassembled and each tube was washed and sieved a second time. All associated macrofaunal organisms were sorted, counted and identified to the lowest possible taxonomic level. Specimens whose identification was unclear were sent to experts for identification and/or description. Trophic guilds from the literature (symbiont host, bacterivore, scavenger/detritivore or predator) were compiled for each vent species (Table 1). For species with unknown diets, the compilation was based on trophic guilds identified from closely related species (within the same family). These were then compared to our isotopic results (see below).

\subsubsection{Habitat complexity and biomass}

The Ridgeia piscesae tubes create a three-dimensional (3-D) structure for other vent animals to colonise. An estimation of the tubeworm surface area available for the fauna and the volume for each sample provided a proxy for habitat complexity. Assuming that the tubes are cylinders erected vertically, tubeworm surface area was estimated by measuring lengthwise and crosswise (i.e. diameter) $10 \%$ of the tubeworm tubes randomly selected. For each tubeworm sample, species density is therefore expressed as the number of indi- 
Table 1. Trophic guild and nutritional modes of macrofaunal species associated with the Ridgeia piscesae tubeworm assemblages of the Grotto hydrothermal edifice (Main Endeavour Field, Juan de Fuca Ridge). An asterisk (*) marks the original description of the species.

\begin{tabular}{|c|c|c|}
\hline Species & Trophic guild - nutritional mode & Reference(s) \\
\hline \multicolumn{3}{|l|}{ Annelida } \\
\hline \multicolumn{3}{|l|}{ Polychaeta } \\
\hline \multicolumn{3}{|l|}{ Siboglinidae } \\
\hline Ridgeia piscesae & Symbiotic & Jones (1985)*; Southward et al. (1995); Bergquist et al. (2007); this study \\
\hline \multicolumn{3}{|r|}{$\mathrm{x}^{2}$} \\
\hline Nicomache venticola & Bacterivore - surface deposit feeder or grazer & Blake and Hilbig (1990)*; Bergquist et al. (2007); this study \\
\hline \multicolumn{3}{|l|}{ Dorvilleidae } \\
\hline Ophryotrocha globopalpata & Predator & Blake and Hilbig (1990)*; Bergquist et al. (2007); this study \\
\hline \multicolumn{3}{|l|}{ Orbiniidae } \\
\hline $\begin{array}{l}\text { Berkeleyia sp. nov. } \\
\text { Hesionidae }\end{array}$ & Hesionidae & Jumars et al. (2015); this study \\
\hline Hesiospina sp. nov. ${ }^{\text {a }}$ & Predator & Bonifácio et al. (2018)*; this study \\
\hline \multicolumn{3}{|l|}{ Phyllodocidae } \\
\hline Protomystides verenae & Predator & Blake and Hilbig (1990)*; Bergquist et al. (2007); this study \\
\hline \multicolumn{3}{|r|}{ 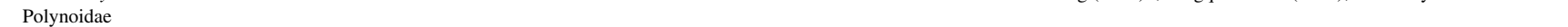 } \\
\hline Branchinotogluma tunnicliffeae & Predator & Pettibone (1988)*; Bergquist et al. (2007); this study \\
\hline Branchinotogluma sp. & Predator & - \\
\hline Lepidonotopodium piscesae & Predator & Pettibone (1988)*; Levesque et al. (2006); Bergquist et al. (2007); this study \\
\hline Levensteiniella kincaidi & Predator & Pettibone (1985)*; Bergquist et al. (2007); this study \\
\hline \multicolumn{3}{|l|}{ Sigalionidae } \\
\hline Pholoe courtneyae & Predator & Blake (1995)*; Sweetman et al. (2013) \\
\hline \multicolumn{3}{|r|}{ 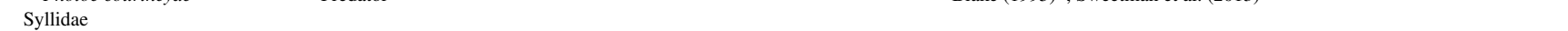 } \\
\hline Sphaerosyllis ridgensis & Predator & Blake and Hilbig (1990)*; Bergquist et al. (2007); this study \\
\hline Alvinellidae & & \\
\hline Paralvinella dela & Bacterivore - surface deposit feeder or grazer; suspension feeder & Detinova $(1988)^{*} ;$ this study \\
\hline Paralvinella palmiformis & Bacterivore - surface deposit feeder or grazer; suspension feeder & Desbruyères and Laubier (1986*, 1991); Levesque et al. (2003); this study \\
\hline Paralvinella pandorae & Bacterivore - surface deposit feeder or grazer; suspension feeder & Desbruyères and Laubier (1986*, 1991); Levesque et al. (2003); this study \\
\hline Paralvinella sulfincola & Bacterivore - surface deposit feeder or grazer; suspension feeder & Tunnicliffe et al. (1993)*; Levesque et al. (2003); this study \\
\hline Ampharetidae & & \\
\hline Amphisamytha carldarei & Scavenger/detritivore - surface deposit feeder or grazer & $\begin{array}{l}\text { Stiller et al. (2013)*; McHugh and Tunnicliffe (1994); Bergquist et al. (2007); } \\
\text { this study }\end{array}$ \\
\hline Ctenodrilidae & & \\
\hline Raricirrus sp. & Bacterivore - surface deposit feeder or grazer & Jumars et al. (2015) \\
\hline Spionidae & & \\
\hline Prionospio sp. & Bacterivore - surface deposit feeder or grazer & Jumars et al. (2015) \\
\hline Mollusca & & \\
\hline Aplacophora & & \\
\hline Solenogastres & & \\
\hline Helicoradomenia juani & Predator & Scheltema and Kuzirian (1991)*; Bergquist et al. (2007); this study \\
\hline Gastropoda & & \\
\hline Buccinidae & & \\
\hline Buccinum thermophilum & Scavenger/detritivore - surface deposit feeder or grazer & Harasewych and Kantor (2002)*; Martell et al. (2002); this study \\
\hline & & \\
\hline Provanna variabilis & Bacterivore - surface deposit feeder or grazer & Warén and Bouchet (1986)*; Bergquist et al. (2007); this study \\
\hline Peltospiridae & & \\
\hline Depressigyra globulus & Bacterivore - surface deposit feeder or grazer & Warén and Bouchet (1989)*; Bergquist et al. (2007); this study \\
\hline Clypeosectidae & & \\
\hline Clypeosectus curvus & Predator & McLean (1989)*; Bergquist et al. (2007); this study \\
\hline Lepetodrilidae & & \\
\hline Lepetodrilus fucensis & Symbiotic; Bacterivore - surface deposit feeder or grazer; suspension feeder & $\begin{array}{l}\text { McLean (1988)*; Fox et al. (2002); Bates et al. (2007); Bergquist et al. (2007); } \\
\text { this study }\end{array}$ \\
\hline Arthropoda & & \\
\hline Arachnida & & \\
\hline Halacaridae & & \\
\hline Copidognathus papillatus & Predator & Krantz (1982)*; Bergquist et al. (2007); this study \\
\hline Amphipoda & & \\
\hline Alicellidae & & \\
\hline Paralicella cf. vaporalis & - & Barnard and Ingram (1990)* \\
\hline Calliopiidae & & \\
\hline Oradarea cf. walkeri & - & Shoemaker (1930)* \\
\hline Leptamphopus sp. & - & - \\
\hline Crustacea & & \\
\hline Philomedidae & & \\
\hline Euphilomedes climax & Bacterivore - surface deposit feeder or grazer & Kornicker $(1991)^{*}$; this study \\
\hline Cytherudidae & & \\
\hline Xylocythere sp. nov. ${ }^{\mathrm{b}}$ & Bacterivore - surface deposit feeder or grazer & Tanaka et al. (2018)*; Maddocks and Steineck (1987); this study \\
\hline Pycnogonida & & \\
\hline Ammotheidae & & \\
\hline Sericosura verenae & Bacterivore - surface deposit feeder or grazer & Child (1987)*; Bergquist et al. (2007); this study \\
\hline Sericosura venticola & Bacterivore - surface deposit feeder or grazer & Child (1987)*; Bergquist et al. (2007); this study \\
\hline Sericosura cf. dissita & Bacterivore - surface deposit feeder or grazer & Child $(2000)^{*} ;$ this study \\
\hline Nemertea & & \\
\hline Unidentified & Predator & - \\
\hline Echinodermata & & \\
\hline Ophiuroidea & - & - \\
\hline
\end{tabular}



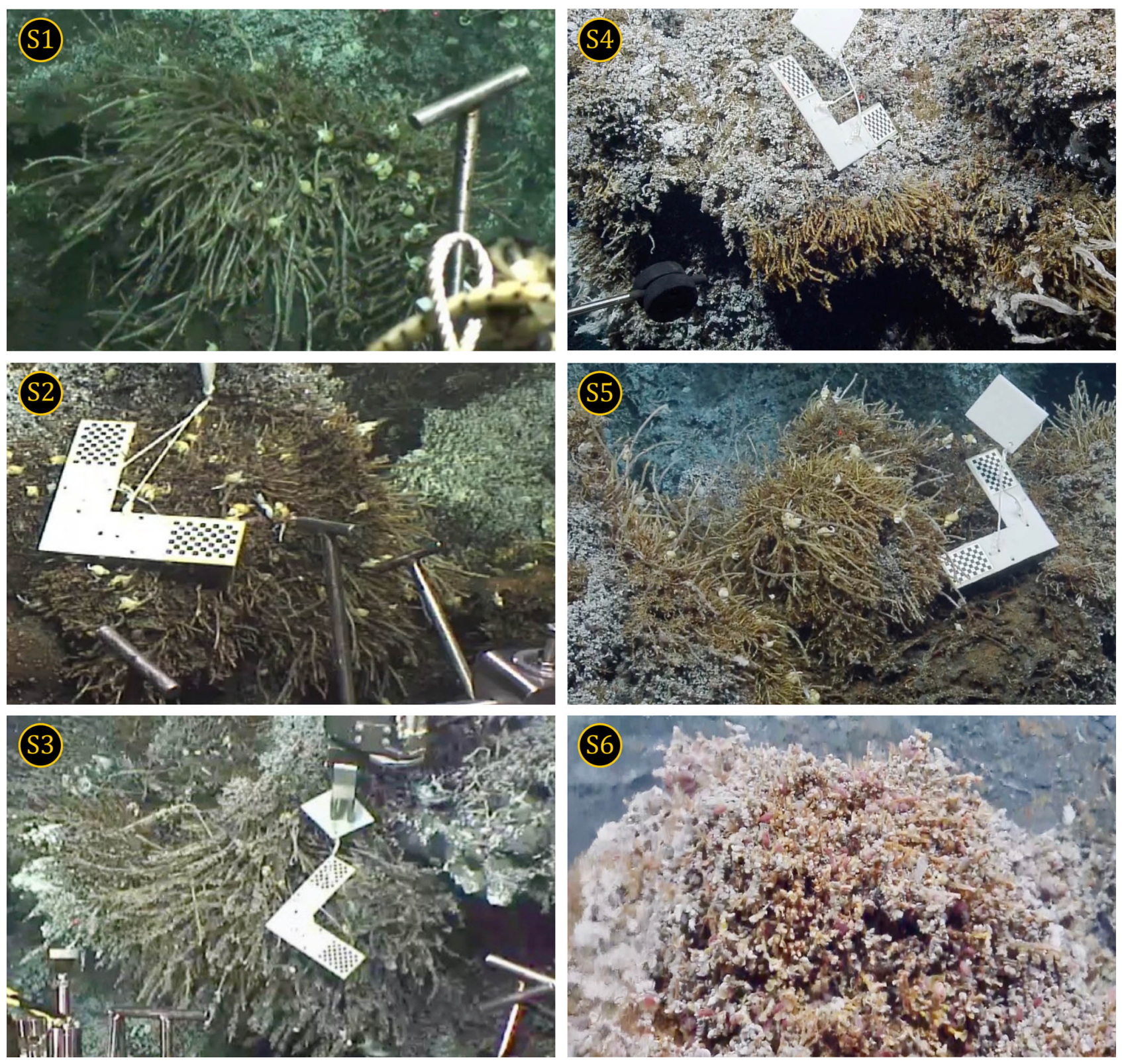

Figure 2. Hydrothermal samples collected on the Grotto edifice (Main Endeavour Field, Juan de Fuca Ridge) during Ocean Networks Canada oceanographic cruises Wiring the Abyss 2015 and 2016.

viduals per square metre of tubeworm surface $\left(\right.$ ind $\left.^{-2}\right)$ to account for this 3-D space (Marcus et al., 2009; Tsurumi and Tunnicliffe, 2001, 2003). Sampling volume was estimated by multiplying the mean tube length by the sampled surface area and faunal density was also expressed as individuals per cubic metre. Biomass estimates were obtained from the total dry mass (DM) of a random sample of a few individuals (310) for each species. The DM of each species corresponds to the mean of individual masses obtained after drying each individual at $80^{\circ} \mathrm{C}$ for $48 \mathrm{~h}$, multiplied by the abundance of each species.

\subsubsection{Stable isotope processing}

Sample preparation for stable isotope analyses was specimen-size-dependent. For large specimens, muscle tissue was dissected and used for stable isotope analyses. In the case of intermediate-size specimens, the gut content was removed before stable isotope analyses. For small species, entire individuals were analysed or pooled to reach the minimum required mass for isotopic analyses. Samples were freeze-dried and ground into a homogeneous powder using a ball mill or agate mortar. Approximately 1.3-1.4 mg of the powder was measured in tin capsules for isotope analyses. 


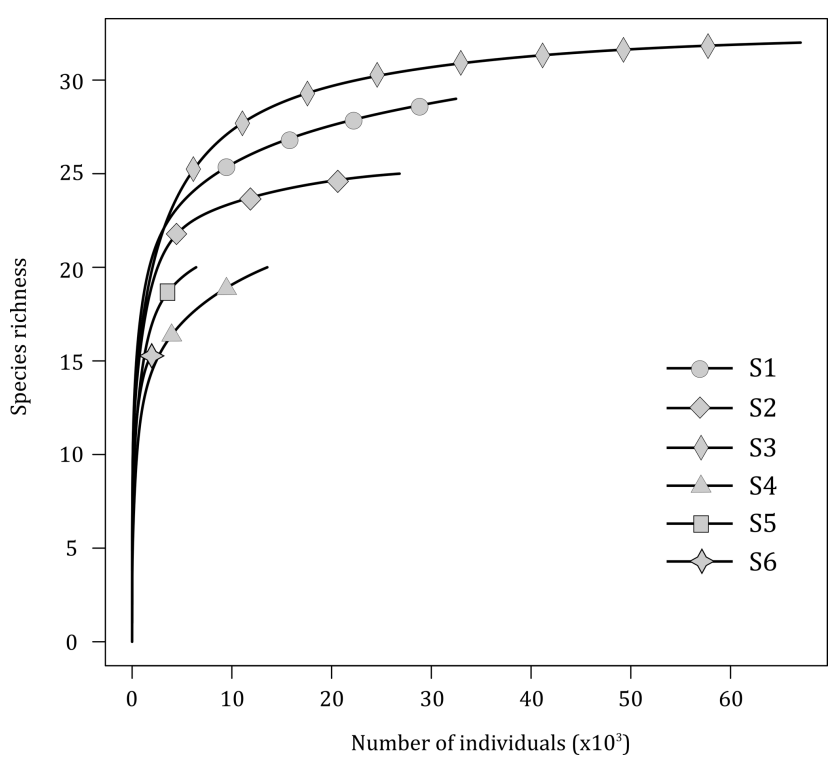

Figure 3. Rarefaction curves for species richness in the six vent samples (S1 to S6) collected on the Grotto hydrothermal edifice.

For species containing carbonates (i.e. gastropods, ostracods, amphipods, etc.), individuals were acidified to remove inorganic carbon. Acidification was carried out by the addition of $0.1 \mathrm{M} \mathrm{HCl}$. The samples were then dried at $60^{\circ} \mathrm{C}$ for $24 \mathrm{~h}$ under a fume extractor to evaporate the acid. Five replicates per species were analysed. Carbon and nitrogen isotope ratios were determined using a Thermo Scientific FLASH EA 2000 elemental analyser coupled with a Thermo Scientific Delta V Plus isotope ratio mass spectrometer. Values are expressed in $\delta(\% o)$ notation relative to Vienna Pee Dee Belemnite and atmospheric $\mathrm{N}_{2}$ as international standards for carbon and nitrogen, respectively, according to the formula: $\delta^{13} \mathrm{C}$ or $\delta^{15} \mathrm{~N}=\left[\left(R_{\text {sample }} / R_{\text {standard }}\right)-1\right] \times 10^{3}$ (in $\%$ o), where $R$ is ${ }^{13} \mathrm{C} /{ }^{12} \mathrm{C}$ or ${ }^{15} \mathrm{~N} /{ }^{14} \mathrm{~N}$. Analytical precision based on repeated measurements of the same sample was below $0.3 \%$ o for both $\delta^{13} \mathrm{C}$ and $\delta^{15} \mathrm{~N}$.

\subsection{Statistical analyses}

In the present study, Ridgeia piscesae was regarded as a habitat builder and thus discarded from all statistical analyses. Species-effort curves were computed for each faunal sample collected to assess the robustness of the sampling effort. Local diversity (i.e. $\alpha$ diversity) was estimated for each tubeworm sample from several complementary indices (Gray, 2000) using the vegan package in $\mathrm{R}$ (Oksanen et al., 2017): species richness $(S)$, exponential Shannon entropy $(D)$, Simpson's $\left(1-\lambda^{\prime}\right)$ indices of species diversity and Pielou's evenness index $\left(J^{\prime}\right)$.

\section{Results}

\subsection{Species-effort curves, tubeworm structural complexity and diversity}

The rarefaction curves (excluding Ridgeia piscesae; Fig. 3) showed that, overall, the collected samples (S1 to S6) gave a fairly good representation of the species diversity on the Grotto hydrothermal edifice. In 2015, sample S2 (24 species) and S3 (31 species) rarefaction curves seemed to reach a plateau. S1 consisted of a total of 28 macrofaunal species. The samples from the year 2016 exhibited lower species richness and did not reach an asymptote. Samples S4 and S5 both had a macrofaunal species richness of 19 species, while only 14 species were found in sample S6 (Fig. 3).

Tubeworm surface areas and volumes of the samples were used as proxies for habitat complexity provided by the engineer species $R$. piscesae (Table 2). Samples S1 and S3 were characterised by a similar degree of structural complexity, with a tubeworm surface of 4.27 and $4.26 \mathrm{~m}^{2}$, respectively (Table 2). Sample S2 displayed a sampling area of less than half of that of $\mathrm{S} 1$ and $\mathrm{S} 3$ reaching a total tubeworm surface area of $1.63 \mathrm{~m}^{2}$. Samples from 2016 were substantially smaller than those from 2015. Tubeworm surface areas varied between 0.1 and $0.57 \mathrm{~m}^{2}$. To summarise, the tube surface areas of the different samples were as follow: $\mathrm{S} 1>\mathrm{S} 3>\mathrm{S} 2>\mathrm{S} 5>\mathrm{S} 6>\mathrm{S} 4$ (Table 2). Sample volumes were also strongly correlated $\left(R_{\text {adj }}^{2}=0.82 ; p\right.$ value $\left.=0.008\right)$ to the tubeworm surface area for these Grotto samples and thus can be used as an easily measurable proxy to estimate habitat complexity.

Alpha diversity measures showed that S4 displayed the lowest diversity $\left(D=2.605 ; 1-\lambda^{\prime}=0.550\right)$, followed by S6 $\left(D=3.998 ; 1-\lambda^{\prime}=0.633\right)$ and S5 $\left(D=4.348 ; 1-\lambda^{\prime}=\right.$ $0.697)$. The highest diversity values observed were $S 1$ ( $D=$ $\left.5.377 ; 1-\lambda^{\prime}=0.728\right)$, slightly less than S2 $(D=5.398 ; 1-$ $\lambda^{\prime}=0.749$ ) and S3 (Shannon $D=6.053 ; 1-\lambda^{\prime}=0.778$ ). The S2 and S3 samples showed a more even distribution $\left(J^{\prime}\right)$ of individuals among species than the other samples. In contrast, S4 had the lowest evenness $\left(J^{\prime}=0.325\right)$ (Table 2). Species richness was significantly correlated with $R$. piscesae tube length $\left(R_{\mathrm{adj}}^{2}=0.62 ; p\right.$ value $\left.=0.039\right)$.

\subsection{Composition and structure of Grotto vent communities}

The species list and abundances for each sample collected within the Grotto hydrothermal edifice are provided in Table 3. A total of 148005 individuals representing 35 macrofaunal species (excluding Ridgeia piscesae) were identified in the six tubeworm bushes (S1 to S6) sampled on the Grotto edifice. Overall, gastropods (5 species) and polychaetes (18 species), respectively, accounted for $69.5 \pm 18.8 \%$ and $16.3 \pm 11.8 \%$ of the total macrofaunal abundance. The numerically most abundant species were the 
Table 2. Univariate measures of macrofaunal community structure associated with Ridgeia piscesae tubeworm bushes on the Grotto edifice: sample surface area (SSA), tube height (TH), tube diameter (TD), tubeworm surface area (TSA), volume $(V)$, species richness $(S)$, exponential of Shannon entropy $(D)$, Simpson's diversity index $\left(1-\lambda^{\prime}\right)$ and Pielou's evenness $\left(J^{\prime}\right)$.

\begin{tabular}{lrrrrrrrrr}
\hline Sample & SSA $\left(\mathrm{m}^{2}\right)$ & $\mathrm{TH}(\mathrm{cm}) \pm \mathrm{SD}$ & $\mathrm{TD}(\mathrm{cm}) \pm \mathrm{SD}$ & $\mathrm{TSA}\left(\mathrm{m}^{2}\right)$ & $V\left(\mathrm{~m}^{3}\right)$ & $S$ & $D$ & $1-\lambda^{\prime}$ & $J^{\prime}$ \\
\hline S1 & 0.12 & $17.14 \pm 6.83$ & $4.72 \pm 0.82$ & 4.27 & 0.02 & 28 & 5.377 & 0.728 & 0.505 \\
S2 & 0.06 & $5.32 \pm 2.47$ & $2.24 \pm 0.42$ & 1.63 & $3.4 \times 10^{-3}$ & 24 & 5.398 & 0.749 & 0.531 \\
S3 & 0.12 & $19.91 \pm 9.31$ & $5.48 \pm 1.13$ & 4.26 & 0.02 & 31 & 6.053 & 0.778 & 0.524 \\
S4 & 0.02 & $7.15 \pm 2.45$ & $2.48 \pm 0.57$ & 0.57 & $1.1 \times 10^{-3}$ & 19 & 2.605 & 0.55 & 0.325 \\
S5 & 0.02 & $3.46 \pm 0.85$ & $1.91 \pm 0.34$ & 0.10 & $5.4 \times 10^{-4}$ & 19 & 4.348 & 0.697 & 0.499 \\
S6 & 0.01 & $6.15 \pm 2.80$ & $2.14 \pm 0.43$ & 0.18 & $7.5 \times 10^{-3}$ & 14 & 3.998 & 0.633 & 0.525 \\
\hline
\end{tabular}

gastropods Lepetodrilus fucensis and Depressigyra globulus as well as the polychaete Amphisamytha carldarei. The highest macrofaunal densities were observed in samples S5 (59450 ind $\left.\mathrm{m}^{-2}\right)$, S4 (23 784 ind $\left.^{-2}\right)$, S3 (15 452 ind $^{-2}$ ) and S2 (13748 ind $\mathrm{m}^{-2}$ ), whereas S1 and S6 had the lowest densities, with 7212 and 6518 ind $\mathrm{m}^{-2}$, respectively. A high percentage $(30 \%)$ of the species was only found in one or two samples.

More specifically, $\mathrm{S} 1$ was dominated by gastropod species such as L. fucensis, D. globulus and Provanna variabilis (Table 3). High densities contrasted with low biomass were observed for the ampharetid polychaete A. carldarei and the syllid polychaete Sphaerosyllis ridgensis. S2 was also dominated by $L$. fucensis, D. globulus and A. carldarei, with, however, a high proportion of ostracods Euphilomedes cli$\max$ (Table 3). S3 was largely dominated by A. carldarei and, to a lesser extent, was almost equally dominated by $L$. fucensis and D. globulus. Polychaetes were also dominant, with the presence of $S$. ridgensis, the dorvilleid Ophryotrocha globopalpata and the maldanid Nicomache venticola. There were high densities of $P$. variabilis, the solenogaster Helicoradomenia juani, the halacarid Copidognathus papillatus, the ostracod Xylocythere sp. nov. and the pycnogonid Sericosura verenae (Table 3). S4 was dominated by $L$. fucensis and $D$. globulus and, to a lesser extent, by the alvinellid polychaete Paralvinella palmiformis (Table 3). S5 was also dominated by $L$. fucensis and D. globulus, followed by E. climax and P. variabilis (Table 3). Finally, S6 was also dominated $L$. fucensis and D. globulus and, to a lesser extent, by A. carldarei and the alvinellid polychaete Paralvinella pandorae (Table 3).

\section{3 $\delta^{13} \mathrm{C}$ and $\delta^{15} \mathrm{~N}$ isotopic composition}

$\delta^{13} \mathrm{C}$ values of the vent fauna ranged from -33.4 to $-11.8 \%$ o among the different samples (Fig. 4). In more details, $\delta^{13} \mathrm{C}$ values ranged from -33.4 to $-13.5 \%$ o for $\mathrm{S} 1$, from -33.4 to $-15.4 \%$ for S2 and from -32.4 to $-14.7 \%$ for S3. Samples from S4, S5 and S6 displayed slightly narrower $\delta^{13} \mathrm{C}$ ranges, varying from -30.3 to $-12.5 \%$, from -31.3 to $-14.8 \%$ and from -32.3 to $-11.8 \%$, respectively; most species were enriched in ${ }^{13} \mathrm{C}$ relative to the $\mathrm{S} 1, \mathrm{~S} 2$ and $\mathrm{S} 3$ samples (Fig. 4). Overall, the gastropod Provanna variabilis (species no. 2) was the most depleted in ${ }^{13} \mathrm{C}$, with values around $-32.2 \%$ ( $( \pm 1.2 \% o$ ). In contrast, Ridgeia piscesae siboglinids (species no. 1) showed the highest $\delta^{13} \mathrm{C}$ values, with constant values around $-14.7 \%$ ( $( \pm 1.0 \%)$. The range of $\delta^{15} \mathrm{~N}$ values in faunal assemblages varied between -8.5 and $9.4 \%$ (Fig. 4). Especially, S1 values ranged from 0.3 to $8.4 \%$, S2 from 0.4 to $9.2 \%$, S3 from -2.7 to $8.3 \%$, S4 from -1.3 to $8.7 \%$, S5 from -1.1 to $6.4 \%$ and S6 from -8.5 to $9.4 \%$ (Fig. 4). Generally, 15 species showed a $\delta^{15} \mathrm{~N}>5 \%$ o in S1, S2 and S3 assemblages but only 4 species were over $5 \%$ in $\delta^{15} \mathrm{~N}$ in $\mathrm{S} 4, \mathrm{~S} 5$ and $\mathrm{S} 6$. In contrast to their $\delta^{13} \mathrm{C}$ values, $P$. variabilis and $R$. piscesae displayed similar and relatively stable $\delta{ }^{15} \mathrm{~N}$ values among samples with $0.3 \% \circ( \pm 0.8 \% \circ)$ and $1.5 \%$ ( $( \pm 1.1 \%$ ) , respectively.

\subsection{Biomass distribution in Grotto vent food webs}

The projection of the species isotopic ratios weighted by biomass is useful for estimating the relative contributions of the different trophic pathways within the vent assemblages (Fig. 5). In our study, there were similar patterns of biomass distribution in the six sampled assemblages. In all six samples, the ecosystem engineering polychaete Ridgeia piscesae (species no. 1) represented the highest proportion of biomass $(69.3 \pm 16 \%)$. However, as it was considered to be a structuring species of the ecosystem, it was not included in the following biomass distribution analysis. With a total proportion of biomass ranging from 78.9 to $95.8 \%(89.6 \pm 6.8 \%)$ across samples, gastropods seemed to play an important role in the trophic food web of communities associated with the siboglinid tubeworms. The gastropod biomass was dominated by Lepetodrilus fucensis (species no. 4), which accounted for 31.5 to $82.8 \%$ $(55.8 \pm 18.3 \%)$ of the total biomass. In addition to $L$. fucensis, the gastropods Depressigyra globulus (species no. 3), Provanna variabilis (species no. 2) and Buccinum thermophilum (species no. 5) showed relatively high proportions of biomass within the different samples, ranging from 5.6 to $36.6 \%(16.5 \pm 13.8 \%), 0.6$ to $26.3 \%(10.9 \pm 9.8 \%)$ and 0 to $16.1 \%(6.4 \pm 6.8 \%)$, respectively (Fig. 5). However, in some samples, other species also significantly contributed to 


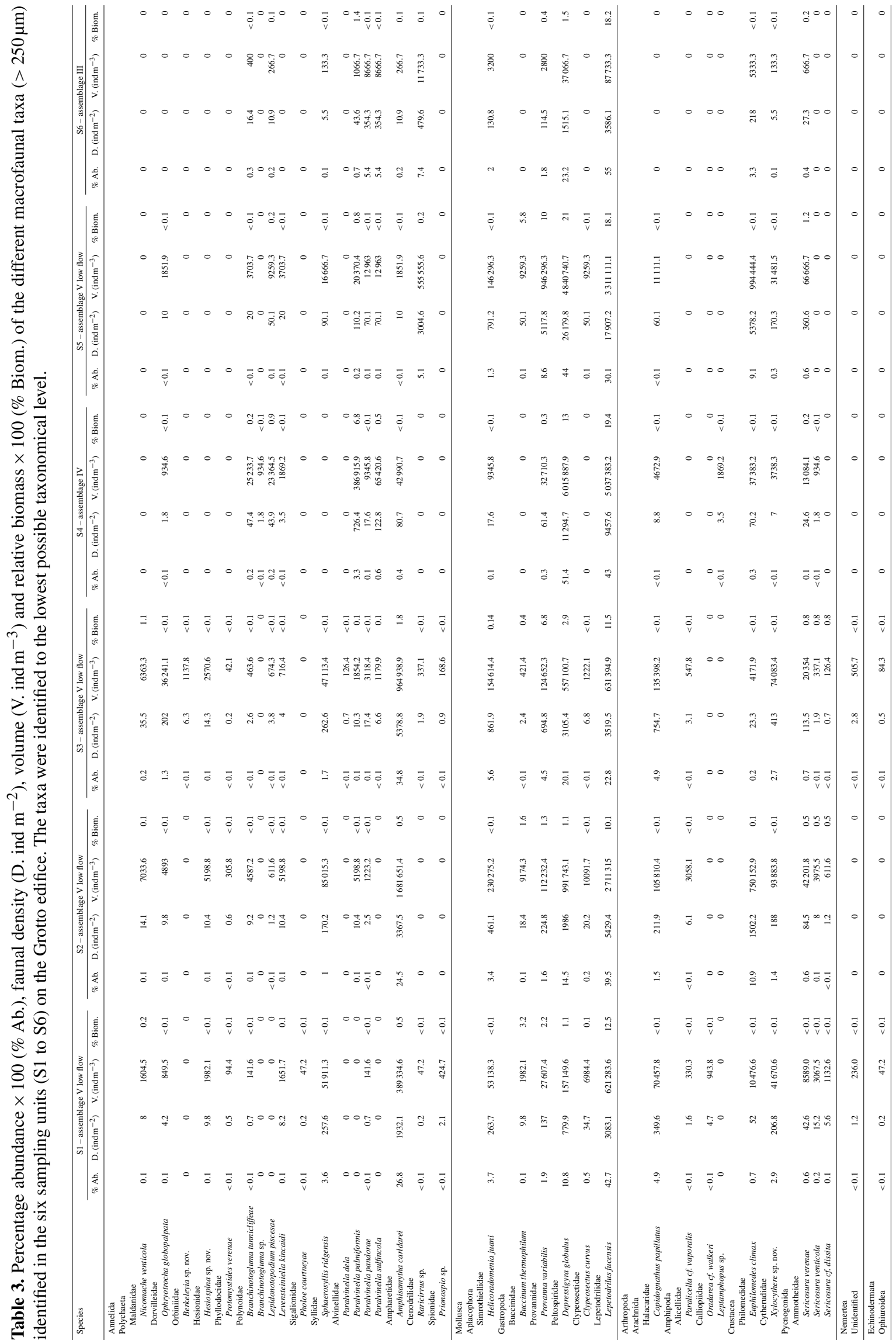




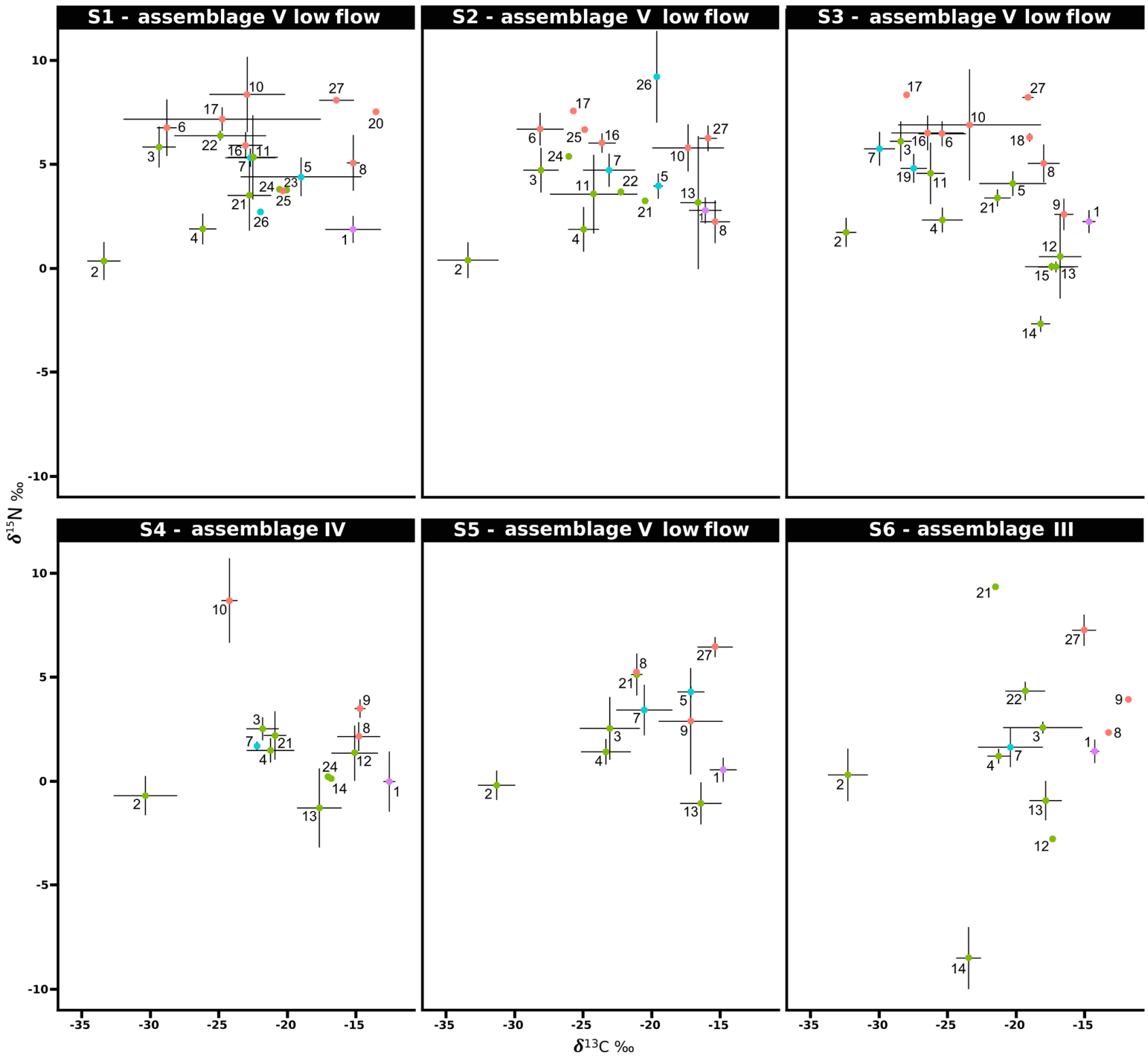

Figure 4. Stable isotope bi-plots showing vent consumers' isotope signatures (mean $\delta^{13} \mathrm{C}$ versus $\delta^{15} \mathrm{~N}$ values \pm standard deviation) for the six vent assemblages sampled on the Grotto hydrothermal edifice. Each vent species is designated by a number: 1 - Ridgeia piscesae; 2 - Provanna variabilis; 3 - Depressigyra globulus; 4 - Lepetodrilus fucensis; 5 - Buccinum thermophilum; 6 - Clypeosectus curvus; 7 - Amphisamytha carldarei; 8 - Branchinotogluma tunnicliffeae; 9 - Lepidonotopodium piscesae; 10 - Levensteiniella kincaidi; 11 Nicomache venticola; 12 - Paralvinella sulfincola $; 13$ - Paralvinella palmiformis; 14 - Paralvinella pandorae; 15 - Paralvinella dela; 16 Hesiospina sp. nov.; 17 - Sphaerosyllis ridgensis; 18 - Ophryotrocha globopalpata; 19 - Berkeleyia sp. nov.; 20 - Protomystides verenae; 21 - Sericosura sp.; 22 - Euphilomedes climax; 23 - Xylocythere sp. nov.; 24 - Copepoda; 25 - Copidognathus papillatus; 26 - Paralicella cf. vaporalis; 27 - Helicoradomenia juani. Known trophic guilds are distinguished by a colour code: pink - symbiont; green - bacterivores; blue - scavengers/detritivores; red - predators. For more information on the interpretation of guilds, please consult the web version of this paper.

the total biomass. For example, in S3, the polychaete Amphisamytha carldarei (species no. 7) contributed substantially $(7.2 \%)$ to the total biomass. Similarly, in S4, the polychaete Paralvinella palmiformis (species no. 13) contributed to $16.4 \%$ of the total biomass.

\section{Discussion}

\subsection{Communities and diversity}

Hydrothermal ecosystems of the north-east Pacific are dominated by dense populations of the tubeworm Ridgeia pisce- 


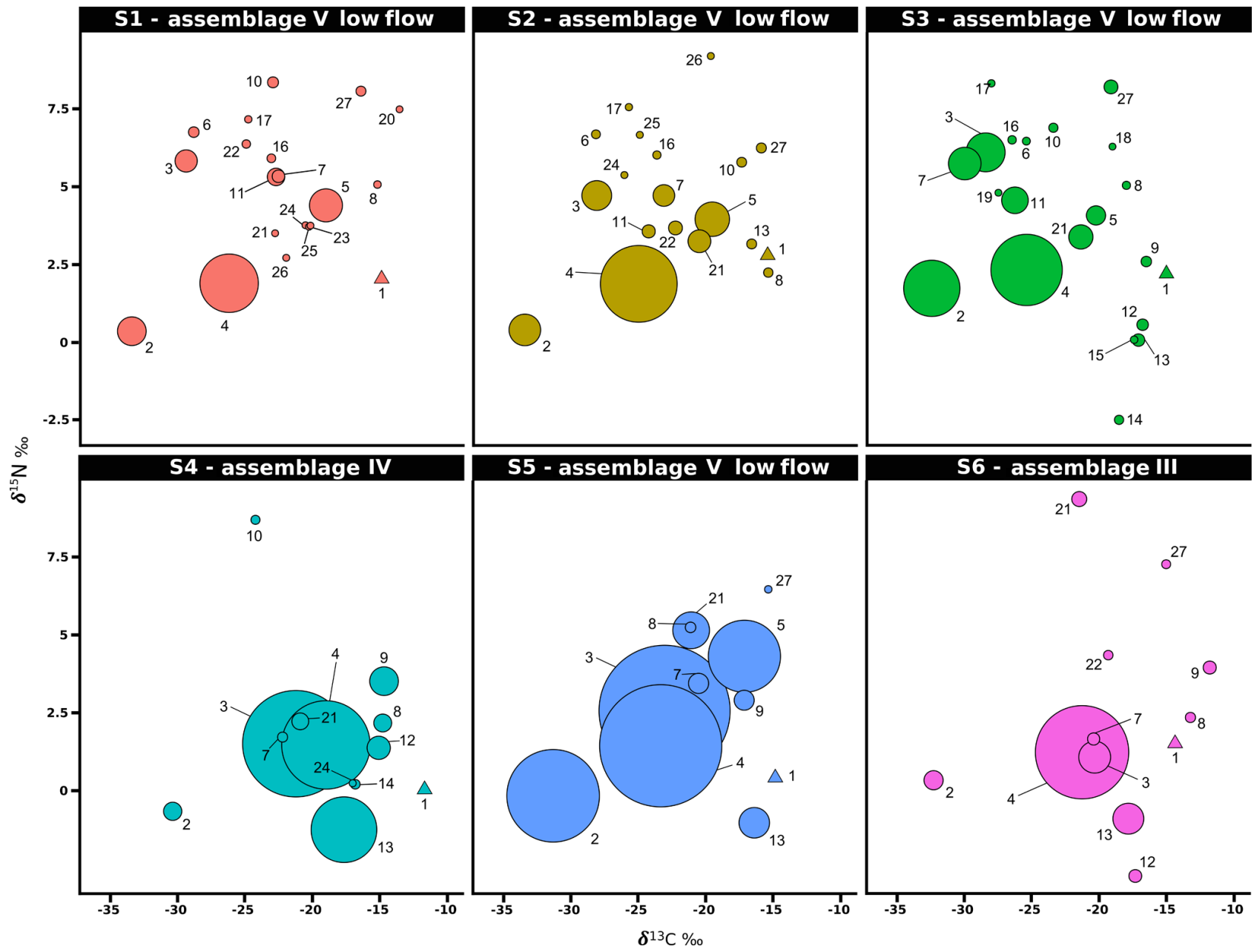

Figure 5. Stable isotope bi-plots showing vent consumers' isotope signatures weighted by biomass per square metre of tubeworms (filled circles) for the six vent assemblages (S1 to S6) sampled on the Grotto hydrothermal edifice. Considered as a habitat, the biomass of Ridgeia piscesae (denoted by a triangle symbol) is not shown. Each vent species is designated by a number: 1 - Ridgeia piscesae; 2 - Provanna variabilis; 3 - Depressigyra globulus; 4 - Lepetodrilus fucensis; 5 - Buccinum thermophilum; 6 - Clypeosectus curvus; 7 - Amphisamytha carldarei; 8 - Branchinotogluma tunnicliffeae; 9 - Lepidonotopodium piscesae; 10 - Levensteiniella kincaidi; 11 - Nicomache venticola; 12 - Paralvinella sulfincola; 13 - Paralvinella palmiformis; 14 - Paralvinella pandorae; 15 - Paralvinella dela; 16 - Hesiospina sp. nov.; 17 - Sphaerosyllis ridgensis; 18 - Ophryotrocha globopalpata; 19 - Berkeleyia sp. nov.; 20 - Protomystides verenae; 21 - Sericosura sp.; 22 - Euphilomedes climax; 23 - Xylocythere sp. nov.; 24 - Copepoda; 25 - Copidognathus papillatus; 26 - Paralicella cf. vaporalis; 27 Helicoradomenia juani. For legibility, the biomass of $P$. pandorae in collection S6 is not shown.

sae. In this study, a total of 36 macrofaunal species (including $R$. piscesae) were found in the six tubeworm bushes sampled on the Grotto edifice, which is consistent with previous knowledge of the community in the region (Bergquist et al., 2007). In this study, macrofaunal species richness was slightly lower than that observed at the Easter Island hydrothermal site on the Main Endeavour Field, where a total of 39 species has been identified in a single $R$. piscesae bush (Bergquist et al., 2007). Tsurumi and Tunnicliffe (2003) reported the presence of 39 macrofaunal species in 25 collections from the Axial Segment (JdFR), but lower values have been reported on other segments, with 24 species in seven collections from the Cleft Segment (JdFR) and 19 species in two collections from the CoAxial Segment (JdFR). These levels of diversity are lower than that found in Riftia pachyptila bushes on the East Pacific Rise, where species richness in eight collections reached 46 species (Govenar et al., 2005). Macrofaunal diversity was also lower than those obtained in ecosystem engineering mussel beds from Lucky Strike on the Mid-Atlantic Ridge, with 41 taxa identified (Sarrazin et al., 2015), or from the northern and southern East Pacific Rise, with richnesses of 61 and 57 species, respectively (Van Dover, 2003). Variation between sites and regions may be related to discrepancies in sampling effort and methodologies. Alternatively, faunal dissimilarities between biogeographic regions may be closely related to the 
geological context, species colonisation history, connectivity to neighbouring basins, presence of geographic barriers (transform faults, hydrodynamic processes, depths, etc.), stability of hydrothermal activity, age of the vent system and distances between sites (Van Dover et al., 2002).

Tubeworm bushes sampled on the Grotto edifice were characterised by the dominance of a few species such as Lepetodrilus fucensis, Depressigyra globulus and Amphisamytha carldarei. Numerical dominance by a few species is a pattern that has also been reported from other hydrothermal sites of the world oceans: the Mid-Atlantic Ridge (Cuvelier et al., 2011; Sarrazin et al., 2015), the East Pacific Rise (Govenar et al., 2005), JdFR (Sarrazin and Juniper, 1999; Tsurumi and Tunnicliffe, 2001) and the southern East Pacific Rise (Matabos et al., 2011). Polychaetes were the most diverse taxa, representing half of the macrofaunal species richness with 18 species. Similar results have been reported within $R$. piscesae bushes on Easter Island, with the identification of 23 polychaete species (Bergquist et al., 2007). Although the dominant species were similar among samples, variation between samples mainly involved the relative abundance of the few dominant species and the identity of the "rare" species. These variations may result from differences in sampling strategies between years. The areas sampled in 2016 were smaller than in 2015, and a problem with the sampling boxes may have led to the loss of some individuals, even though not visible from videos recorded by the submersible. Variation in species richness and diversity among samples may also depend on the presence of environmental gradients, created by the mixing between ambient seawater and hydrothermal effluents (Sarrazin et al., 1999). Unfortunately, no environmental data were recorded with our samples. However, physical and chemical conditions are known to change along the ecological succession gradient on the MEF from newly opened habitat characterised by high temperature and sulfide concentrations, colonised by the sulfide worm Paralvinella sulfincola, to mature communities in low diffuse venting areas characterised by low temperatures and sulfide concentrations and colonised by long skinny $R$. piscesae tubeworms (Sarrazin et al., 1997). Tubeworm samples S1 and S3 were visually recognised as type V lowflow assemblages (Sarrazin et al., 1997), an advanced stage in the ecological succession characterised by longer tubes $(18.5 \pm 3.3 \mathrm{~cm})$ and thus a higher level of structural complexity. Both samples showed the highest species richness, diversity and most complex food webs, suggesting a strong influence of engineer species and the importance of biogenic structure in the diversification and persistence of the local resident fauna. By increasing the number of micro-niches available for vent species, the 3-D structure of $R$. piscesae bushes helps to increase the environmental heterogeneity and thereby promotes species richness and diversity at assemblage scales (Jones et al., 1997; Tsurumi and Tunnicliffe, 2003). As mentioned by several authors (Bergquist et al., 2003; Govenar et al., 2002; Tsurumi and Tunnicliffe,
2003), various ecological mechanisms may explain the influence of $R$. piscesae tubeworms on local diversity: new habitats generated by tubeworm bushes provide (i) a substratum for attachment and colonisation, (ii) interstitial spaces among intertwined tubes, increasing habitat gradients and therefore the number of ecological niches, (iii) a refuge to avoid predators and to reduce the physiological stress related to abiotic conditions, and (iv) a control on the transport of hydrothermal vent flow and nutritional resource availability. Samples S2 and S5, also identified as type V low-flow assemblages (Sarrazin et al., 1997), presented shorter tube lengths than S1 and S3, which might explain the lower species richness in these two samples. High densities of $A$. carldarei in $R$. piscesae tubeworm bushes (up to $93.4 \%$ ) may be related to this ampharetid's tolerance to environmental conditions and, therefore, to their ability to take advantage of a wide range of ecological niches (McHugh and Tunnicliffe, 1994). Similar to L. fucensis, A. carldarei is characterised by early maturity and high fecundity, contributing to the success of this species in vent habitats (McHugh and Tunnicliffe, 1994). The dominance of gastropods L. fucensis and D. globulus as well as the relatively high abundance of the Paralvinella polychaete species in samples S4 and S6 suggest that they belong to lower succession levels, corresponding to transitory states between types III and IV assemblages described by Sarrazin et al. (1997). The latter two samples were characterised by low species richness and diversities. We hypothesise that the numerical dominance of gastropods negatively affected species diversity by monopolising space and nutritional resources and by potentially grazing new recruits, therefore reducing the settlement of other vent species. As suggested by Sarrazin et al. (2002), the development of tubeworm bushes along the successional dynamics leads to the diversification of ecological and trophic niches, which may increase the complexity of the food web.

\subsection{Trophic structure of tubeworm assemblages}

The Ridgeia piscesae tubeworm assemblages of the Grotto hydrothermal edifice harbour a relatively diverse heterotrophic fauna. The isotopic analyses conducted on the most dominant vent macrofaunal species within the bushes revealed a high degree of resemblance in trophic structure among the six faunal samples. In this study, the position of species in the food webs (trophic structure) was consistent with the ones reported in Bergquist et al. (2007), with, however, less variability in carbon and nitrogen stable isotopes.

Hydrothermal food webs are generally based on two main energetic pathways: the transfer of energy from symbionts to host invertebrates and the consumption of free-living microbial production (Bergquist et al., 2007). In the present study, the contrasting isotope compositions of the gastropods Provanna variabilis, Lepetodrilus fucensis and the polychaete $R$. piscesae suggest a wide range of isotopically distinct, symbiotic and/or free-living microbial production 
available to primary consumers. The high $\delta^{13} \mathrm{C}$ values of $R$. piscesae were associated with chemosynthetic endosymbiosis linked to thiotrophic symbionts (Hügler and Sievert, 2011). Despite $R$. piscesae contributing to $86 \%$ of the total biomass, a low number of species displayed similar $\delta^{13} \mathrm{C}$ values, suggesting that specialist species deriving the majority of their food sources from siboglinid tubeworms are rare. Similar observations, where engineer species contribute to the community more as a habitat than as a food source, have been reported in $R$. piscesae tubeworm bushes from the Easter Island vent site (Bergquist et al., 2007) and in Bathymodiolus azoricus mussel bed assemblages on the Tour Eiffel hydrothermal edifice (Lucky Strike, Mid-Atlantic Ridge) (De Busserolles et al., 2009). The low degree of exploitation of this large biomass and potential food resource suggests that rather than playing a trophic role, $R$. piscesae would primarily play a structuring role in vent ecosystems. Nevertheless, the $\delta^{13} \mathrm{C}$ and $\delta^{15} \mathrm{~N}$ values of polynoids Branchinotogluma tunnicliffeae and Lepidonotopodium piscesae were consistent with a predatory diet including $R$. piscesae tubeworms. Moreover, the predation of tubeworms by polynoids is often observed, as shown on a video sequence from the ecological observatory module TEMPO-mini, deployed on the Grotto hydrothermal edifice (ONC observatory; Video S1 in the Supplement). The ${ }^{13} \mathrm{C}$-depleted stable isotope compositions of $P$. variabilis suggest a possible symbiosis with chemoautotrophic bacteria or reliance on feeding on a very specific free-living microbial community that depends on a ${ }^{13} \mathrm{C}$-depleted carbon source (Bergquist et al., 2007). To date, no study has reported the presence of chemoautotrophic symbionts in P. variabilis, but symbioses have been described for other species from the Provannidae family (Windoffer and Giere, 1997). With an intermediate $\delta^{13} \mathrm{C}$ composition between $R$. piscesae and P. variabilis, L. fucensis gastropods seem to represent a major energetic pathway in these vent communities. Food webs obtained in this study revealed that most vent species display a $\delta^{13} \mathrm{C}$ similar to L. fucensis, but with slightly higher $\delta^{15} \mathrm{~N}$ values. Through its high densities, large biomasses and its position at the base of the food webs, we suggest that $L$. fucensis could play an important role in structuring vent communities. The wide-ranging feeding strategies of this limpet may exert a high pressure on the availability of nutritional resources for others vent species. Likewise, the range of feeding strategies open up more opportunities for L. fucensis, allowing this limpet to take advantage of resources that other species cannot. The four Paralvinella species observed in our samples, which are described as suspension and/or deposit feeders (Desbruyères and Laubier, 1986; Tunnicliffe et al., 1993), displayed low or negative $\delta^{15} \mathrm{~N}$ values. These lowest $\delta^{15} \mathrm{~N}$ values may be related to the nutrition of a microbial pool based on local nitrogen sources. In fact, the ammonium produced during the microbial degradation of organic matter appears to be usually ${ }^{15} \mathrm{~N}$-depleted (Lee and Childress, 1996). Amongst these Paralvinella species, Paralvinella sulfincola, Paralvinella palmi- formis and Paralvinella dela shared the same isotopic niche while $P$. pandorae displays a distinct isotopic composition.

Like in many vent food webs (Van Dover and Fry, 1994; Levesque et al., 2005; Limén et al., 2007), Grotto primary consumers were dominated by grazers and deposit feeders (Table 1). The high diversity, densities and biomass of bacterivores emphasise the importance of free-living bacteria in the establishment and maintenance of the structure of the vent food web (Bergquist et al., 2007). The bacterivore guild was mainly represented by the gastropods $P$. variabilis, Depressigyra globulus and L. fucensis and the polychaetes P. sulfincola, P. palmiformis, $P$. pandorae and P. dela. Like Paralvinella grasslei and Paralvinella bactericola at vent sites of the Guaymas Basin (Portail et al., 2016), the alvinellid species found at Grotto had comparable $\delta^{13} \mathrm{C}$ values but different $\delta^{15} \mathrm{~N}$ signatures. Paralvinella pandorae showed a depleted $\delta^{15} \mathrm{~N}$ signature relative to other alvinellid species. A previous study of isotope variability among three sympatric alvinellid species, $P$. palmiformis, $P$. sulfincola and $P$. pandorae on the JdFR reported that their differences in $\delta^{15} \mathrm{~N}$ isotope composition could be closely related to the presence of food-source partitioning and/or to spatial segregation (Levesque et al., 2003). The comparatively small size of $P$. pandorae compared with other alvinellid species (Desbruyères and Laubier, 1986; Tunnicliffe et al., 1993) may be linked to the presence of interspecific competition for food resources and/or a diet based on an isotopically distinct microbial source. The wide range of $\delta^{13} \mathrm{C}$ signatures in bacterivores, coupled with the high interspecific variability in the isotopic space, suggest a large, diversified microbial pool in the hydrothermal ecosystem and high variability in isotope ratios in dominant microbial taxa. Detritivore/scavenger species were observed at an intermediate trophic level, between the bacterivore and predator feeding guilds. This guild was represented by a low number of species including the gastropod Buccinum thermophilum, the ampharetid Amphisamytha carldarei and the orbiniid Berkeleyia sp. nov. The predator feeding guild was represented by the highest $\delta^{15} \mathrm{~N}$ values. High predator diversity was found in our vent assemblages and was associated with a wide range of $\delta^{13} \mathrm{C}$ values, covering the isotopic spectrum of lower trophic-level consumers (i.e. bacterivores as well as scavengers/detritivores). This guild of predators appears to be dominated by polychaetes, which tend to show the highest $\delta^{15} \mathrm{~N}$ values. The syllid Sphaerosyllis ridgensis, the polynoid Levensteiniella kincaidi and the hesionid Hesiospina sp. nov. displayed the highest $\delta^{15} \mathrm{~N}$ values, suggesting that they play the role of predators in the benthic food web. Similarly, the solenogaster Helicoradomenia juani consistently displayed higher $\delta^{15} \mathrm{~N}$ values than other molluscs, indicating a predator trophic position. The presence of Zoarcidae eelpouts Pachycara gymninium and Oregoniidae spider crabs Macroregonia macrochira on the Grotto edifice, not sampled but observed in the video recorded by the TEMPO-mini ecological module, could also play the role of predator within the ecosystem. 
Except for the polynoid L. kincaidi, whose isotopic variability seemed to reveal a nutrition based on highly diversified food resources, stable isotope analyses conducted on predators revealed narrow ranges of $\delta^{13} \mathrm{C}$ and $\delta^{15} \mathrm{~N}$ values at the species scale, suggesting the dominance of specialist feeding strategies, as was the case for bacterivores. An accurate assessment of the isotopic composition of food sources and a description of the meiofaunal communities would be necessary to further increase our understanding of the functioning of these chemosynthetic communities and their trophic structures.

\subsection{Ecological niche partitioning}

Vent species on the Grotto hydrothermal edifice exhibit high isotopic heterogeneity that reflects the complexity of vent ecological food webs. The distribution of species in the bidimensional isotopic space depends on their diets, environmental conditions and biotic interactions, which together define the concept of species ecological niche (Newsome et al., 2007) or the realised species trophic niche (Bearhop et al., 2004). Here, the fact that most of the isotopic space was occupied by isotopically distinct species shows that the available food resources are partitioned within the community. Although the $\delta^{15} \mathrm{~N}$ variability among primary consumers did hinder our inference of trophic levels based on nitrogen isotopes, these communities are unlikely to host more than three trophic levels, given the overall $\delta^{15} \mathrm{~N}$ ranges. Moreover, although predators were quite diverse, they only represented a minor part of the biomass, suggesting that Grotto vent communities are mostly driven by bottom-up processes. Food webs of chemosynthetic ecosystems - such as hydrothermal vents and cold seeps - do not appear to be structured along predator-prey relationships but rather through weak trophic relationships among co-occurring species (Levesque et al., 2006; Portail et al., 2016). Habitat and/or trophic partitioning are important structuring processes at the community scale (Levesque et al., 2003; Levin et al., 2013; Portail et al., 2016). Our results corroborate those from Axial Volcano in the JdFR (Levesque et al., 2006) and the Guaymas basin (Portail et al., 2016), where habitat heterogeneity induces spatial partitioning of trophic niches, leading to a spatial segregation of species and species coexistence (Levesque et al., 2006). Although the observed isotope variability (standard deviations) in Grotto vent species suggests the occurrence of both trophic specialists and generalists within the assemblages, the majority of vent species exhibited low standard deviations, suggesting a predominantly specialist feeding behaviour. As already shown in previous studies of vent sites with alvinellids (Levesque et al., 2003) and sulfidic sediments at methane seeps with dorvilleid polychaetes (Levin et al., 2013) in the north-east Pacific, food partitioning may occur between different species of the same or related taxonomic family, allowing species coexistence through the occupation of distinct trophic niches. Our study confirmed this pattern for alvinellid polychaetes of the genus Paralvinella (Levesque et al., 2006). Hydrothermal vent gastropods were numerically dominant in all Ridgeia piscesae bushes collected on the Grotto edifice, and their isotope compositions were fairly diverse. Gastropods exhibit great diversity in feeding strategies, and as a result they are found in a wide variety of niches where they exploit many food sources (Bates et al., 2005; Bates, 2007). The isotope composition of Provanna variabilis indicated low $\delta^{13} \mathrm{C}$ and $\delta^{15} \mathrm{~N}$ values. Lepetodrilus fucensis gastropods had higher $\delta^{13} \mathrm{C}$ and $\delta^{15} \mathrm{~N}$ values than P. variabilis but a similar range of $\delta^{13} \mathrm{C}$ as Clypeosectus curvus and Depressigyra globulus. However, these latter two species occupy an upper position in the trophic structure of their communities. The great ecological success of L. fucensis in vent habitats may be attributed to a combination of several characteristics. First, this species is characterised by a broad trophic plasticity that includes (i) grazing on siboglinid tubeworms and hard substrata (Fretter, 1988), (ii) active suspension feeding (Bates, 2007), and (iii) harbouring filamentous bacterial epibionts in its gills, which - via endocytosis - may contribute to the animal's nutritional requirements (Bates, 2007; Fox et al., 2002). In addition, the early maturity, high fecundity and continuous gamete production of L. fucensis may help to maintain the large populations on the edifice (Kelly and Metaxas, 2007). Stacking behaviour near fluid emissions also suggests that $L$. fucensis is an important competitor for space and food in the community (Tsurumi and Tunnicliffe, 2003). L. elevatus, the ecological equivalent of L. fucensis on the East Pacific Rise, is prey for the vent zoarcid fish Thermarces cerberus; the reduced limpet population promotes the successful settlement and growth of sessile benthic invertebrates such as tubeworms (Micheli et al., 2002; Sancho et al., 2005). The potential absence of an equivalent predator for $L$. fucensis and the biological characteristics detailed above may explain its ecological success on the north-east Pacific vent sites. In contrast, the nutrition of D. globulus is based on the grazing of organic matter only (Warén and Bouchet, 1989). However, its small size allows it to exploit interstitial spaces that are not available to larger fauna (Bates et al., 2005). Finally, P. variabilis was relatively less abundant than the other two species but appeared to exploit a different thermal niche than L. fucensis and D. globulus (Bates et al., 2005). On the other hand, the isotope composition of Buccinum thermophilum clearly differentiates that species from the other gastropods with higher $\delta^{13} \mathrm{C}$ signatures. Differences in the diets of co-occurring species may contribute to the high abundance and diversity of vent gastropods through niche partitioning (Govenar et al., 2015).

Habitat specialisation among co-occurring vent species may drive differences in their diets (Govenar et al., 2015), facilitating species coexistence in heterogeneous habitats such as hydrothermal ecosystems. We hypothesised that vent food webs display a small-scale spatial structure that is linked to the 3-D architecture of the biogenic structures generated by engineer species. This would promote high interspecific 
trophic segregation. The spatial segregation of trophic niches by environmental gradients limits the occurrence of biotic interactions such as predation and competition for resources between species sharing a common spatial niche (Levesque et al., 2006). Vent food webs may therefore be structured through the interplay between the availability and diversity of food sources and the abiotic and biotic conditions structuring species distribution.

\section{Conclusion}

This study provides the first characterisation of the structure, species diversity and food web structure of macrofaunal assemblages living in Ridgeia piscesae tubeworm bushes on the Grotto hydrothermal edifice. Like many vent structures (Cuvelier et al., 2011; Sarrazin et al., 1997), the Grotto hydrothermal edifice is inhabited by a mosaic of habitats and faunal assemblages that may represent different successional stages. Our results suggest that the development of $R$. piscesae tubeworms introduces complexity and heterogeneity into the hydrothermal environments and exerts a strong influence on ecosystem properties. The structural complexity of these tubeworms enhances community diversity and thereby increases the potential trophic interactions between vent species in the food web. Environmental gradients provided by the interstitial spacing of intertwined tubeworms generate a multitude of ecological niches and contribute to the partitioning of nutritional resources, leading to the species coexistence. Habitat modifications incurred by $R$. piscesae bushes may thus directly stimulate the development of complex food webs. However, despite the increasing complexity in the trophic structure along the ecological succession, the position of species in the isotopic space (trophic structure) did not change across assemblages. A thorough knowledge of hydrothermal biodiversity and ecological functioning of these remote ecosystems is necessary to determine their uniqueness and contribute to the protection and conservation of this natural heritage.

Data availability. The data generated and used in this study are available from SEANOE (SEA scieNtific Open data Edition): http: //doi.org/10.17882/55008 (Lelièvre et al., 2018).

Supplement. The supplement related to this article is available online at: https://doi.org/10.5194/bg-15-2629-2018-supplement.

Author contributions. MM, JS and PL designed and supervised the research project. YL, JM, TD and SH: data acquisition and analyses. YL, MM, JS, GS and PL conceived the ideas and contributed to the interpretation of the results. All authors contributed to the writing process and revised the manuscript.
Competing interests. The authors declare that they have no conflict of interest.

Acknowledgements. The authors thank the captains and crews of the R/V Thomas G. Thompson and E/V Nautilus, the staffs of Ocean Networks Canada and ROV Jason and Hercules pilots during the Ocean Networks Canada Wiring the Abyss cruises in 2015 and 2016. We thank also Kim Juniper and the government of Canada for work permits to study in Canadian waters (XR281, 2015; XR267, 2016). Thanks to Pauline Chauvet for faunal sampling during the ONC 2016 cruise. We are also grateful to the numerous taxonomists around the world who contributed to species identification (Claudia Patricia Arango, James A. Blake, Paulo Henrique Bonifácio, Laure Corbari, Gabin Droual, Lenaick Menot, Hayato Tanaka and Moriaki Yasuhara) and to the laboratory Centre de Recherche sur les Interactions Bassins Versants Écosystèmes Aquatiques (RIVE) at the Université du Québec à Trois-Rivières (Canada) for the isotope sample processing. The authors are particularly grateful to Rachel Boschen and an anonymous referee for their thorough scrutiny of this paper that has greatly improved its final form. The manuscript was professionally edited by Carolyn Engel-Gautier. This research was supported by a NSERC research grant to Pierre Legendre and Ifremer funds. It was also funded by the Laboratoire d'Excellence LabexMER (ANR-10-LABX-19) and co-funded by a grant from the French government under the Investissements d'Avenir programme. This paper is part of the $\mathrm{PhD}$ thesis of Yann Lelièvre carried out under joint supervision between Université de Montréal and Université de Bretagne Occidentale/Ifremer.

Edited by: Tina Treude

Reviewed by: Rachel Boschen and one anonymous referee

\section{References}

Bachraty, C., Legendre, P., and Desbruyères, D.: Biogeographic relationships among deep-sea hydrothermal vent faunas at global scale, Deep-Sea Res. Pt. I, 56, 1371-1378, 2009.

Barnard, J. L. and Ingram, C. L.: Lysianassoid Amphipoda (Crustacea) from deep-sea thermal vents, Smithson, Contrib. to Zool., 4, 1-80, 1990.

Bates, A. E.: Feeding strategy, morphological specialisation and presence of bacterial episymbionts in lepetodrilid gastropods from hydrothermal vents, Mar. Ecol.-Prog. Ser., 347, 87-99, 2007.

Bates, A., Tunnicliffe, V., and Lee, R. W.: Role of thermal conditions in habitat selection by hydrothermal vent gastropods, Mar. Ecol.-Prog. Ser., 305, 1-15, 2005.

Bearhop, S., Adams, C. E., Waldron, S., Fuller, R. A., and Macleod, H.: Determining trophic niche width: a novel approach using stable isotope analysis, J. Anim. Ecol., 73, 1007-1012, 2004.

Bergquist, D., Ward, T., Cordes, E., McNelis, T., Howlett, S., Kosoff, R., Hourdez, S., Carney, R., and Fisher, C.: Community structure of vestimentiferan-generated habitat islands from Gulf of Mexico cold seeps, J. Exp. Mar. Bio. Ecol., 289, 197-222, 2003. 
Bergquist, D. C., Eckner, J. T., Urcuyo, I. A., Cordes, E. E., Hourdez, S., Macko, S. A., and Fisher, C. R.: Using stable isotopes and quantitative community characteristics to determine a local hydrothermal vent food web, Mar. Ecol.-Prog. Ser., 330, 49-65, 2007.

Blake, J. A. and Hilbig, B.: Polychaeta from the vicinity of deepsea hydrothermal vents in the eastern Pacific. II. New species and records from the Juan de Fuca and Explorer Ridge, Pacific Sci., 44, 219-253, 1990.

Blake, J. A.: Family Pholoidae Kinberg, 1858, in Taxonomic atlas of the benthic fauna of the Santa Maria Basin and Western Santa Barbara Channel 5 - The Annelida Part 2, Polychaeta: Phyllodocida (Syllidae and scale-bearing families), Amphinomida, and Eunicida. Santa Barbara Museum of Natural History. Santa Barbara, 175-188, 1995.

Bonifácio, P., Lelièvre, Y., and Omnes, E.: New species and phylogenetic insights in Hesiospina (Annelida, Hesionidae), Zootaxa, submitted, 2018.

Bourbonnais, A., Lehmann, M. F., Butterfield, D. A., and Juniper, S. K.: Subseafloor nitrogen transformations in diffuse hydrothermal vent fluids of the Juan de Fuca Ridge evidenced by the isotopic composition of nitrate and ammonium, Geochem. Geophy. Geosy., 13, 1-23, 2012.

Child, A. C.: Ammothea verenae and Sericosura venticola, two new hydrothermal vent-associated pycnogonids from the northeast Pacific, Proc. Biol. Soc. Washingt., 100, 892-901, 1987.

Child, A. C.: Sericosura dissita, n. sp., a third hydrothermal vent Pycnogonida described from the northeast Pacific, and other known vent species, Species Divers. an Int. J. Taxon. Syst. speciation, Biogeogr. life Hist. Res. Anim., 5, 1-6, 2000.

Childress, J. J. and Fisher, C. R.: The biology of hydrothermal vent animals: physiology, biochemistry, and autotrophic symbioses, Oceanogr. Mar. Biol. Annu. Rev., 30, 337-441, 1992.

Conway, N. M., Kennicutt, M. C., and Van Dover, C. L.: Stable isotopes in the study of marine chemosynthetic-based ecosystems, in: Stable isotopes in ecology and environmental science, Blackwell Scientific, Oxford, 158-186, 1994.

Cuvelier, D., Sarradin, P.-M., Sarrazin, J., Colaço, A., Copley, J. T., Desbruyères, D., Glover, A. G., Serrao Santos, R., and Tyler, P. A.: Hydrothermal faunal assemblages and habitat characterisation at the Eiffel Tower edifice (Lucky Strike, Mid-Atlantic Ridge), Mar. Ecol., 32, 243-255, 2011.

Cuvelier, D., De Busserolles, F., Lavaud, R., Floc'h, E., Fabri, M.C., Sarradin, P. M., and Sarrazin, J.: Biological data extraction from imagery - How far can we go? A case study from the MidAtlantic Ridge, Mar. Environ. Res., 82, 15-27, 2012.

Cuvelier, D., Legendre, P., Laes, A., Sarradin, P.-M., and Sarrazin, J.: Rhythms and community dynamics of a hydrothermal tubeworm assemblage at Main Endeavour Field - A multidisciplinary deep-sea observatory approach, PLoS One, 9, e96924, https://doi.org/10.1371/journal.pone.0096924, 2014.

De Busserolles, F., Sarrazin, J., Gauthier, O., Gélinas, Y., Fabri, M.C., Sarradin, P.-M., and Desbruyères, D.: Are spatial variations in the diets of hydrothermal fauna linked to local environmental conditions?, Deep-Sea Res. Pt. II, 56, 1649-1664, 2009.

Delaney, J. R., Robigou, V., McDuff, R. E., and Tivey, M. K.: Geology of a vigorous hydrothermal system on the Endeavour Segment, Juan de Fuca Ridge, J. Geophys. Res., 97, 19663-19682, 1992.
Desbruyères, D. and Laubier, L.: Les Alvinellidae, une famille nouvelle d'annélides polychètes inféodées aux sources hydrothermales sous-marines: systématique, biologie et écologie, Can. J. Zool., 64, 2227-2245, 1986.

Desbruyères, D. and Laubier, L.: Systematics, phylogeny, ecology and distribution of the Alvinellidae (Polychaeta) from deep-sea hydrothermal vents, Ophelia, 5, 31-45, 1991.

Detinova, N. N.: New species of polychaetous annelids from hydrothermal vents of the Juan-de-Fuca Ridge (Pacific Ocean), Zool. Zhurnal, 67, 858-864, 1988.

Devey, C. W., Fisher, C. R., and Scott, S.: Responsible science at hydrothermal vents, Oceanography, 20, 162-171, 2007.

Dreyer, J. C., Knick, K. E., Flickinger, W. B., and Van Dover, C. L.: Development of macrofaunal community structure in mussel beds on the northern East Pacific Rise, Mar. Ecol.-Prog. Ser., 302, 121-134, 2005.

Erickson, K. L., Macko, S. A., and Van Dover, C. L.: Evidence for a chemoautotrophically based food web at inactive hydrothermal vents (Manus Basin), Deep-Sea Res. Pt. II, 56, 1577-1585, 2009.

Fisher, C., Takai, K., and Le Bris, N.: Hydrothermal vent ecosystems, Oceanography, 20, 14-23, 2007.

Fox, M., Juniper, S. K., and Vali, H.: Chemoautotrophy as a possible nutritional source in the hydrothermal vent limpet Lepetodrilus fucensis, Cah. Biol. Mar., 43, 371-376, 2002.

Fretter, V.: New archaeogastropod limpets from hydrothermal vents?; supermfamily Lepetodrilacea, Philos. T. R. Soc. London, 318, 33-82, 1988.

Galkin, S. V. and Goroslavskaya, E. I.: Bottom fauna associated with Bathymodiolus azoricus (Mytilidae) mussel beds in the hydrothermal fields of the Mid-Atlantic Ridge, Oceanology, 50, 51$60,2010$.

Gaudron, S. M., Lefebvre, S., Nunes Jorge, A., Gaill, F., and Pradillon, F.: Spatial and temporal variations in food web structure from newly-opened habitat at hydrothermal vents, Mar. Environ. Res., 77, 129-140, 2012.

Gollner, S., Zekely, J., Van Dover, C. L., Govenar, B., Le Bris, N., Nemeschkal, H. L., Bright, M., Hole, W., and Hole, W.: Benthic copepod communities associated with tubeworm and mussel aggregations on the East Pacific Rise, Cah. Biol. Mar., 47, 397-402, 2006.

Govenar, B. and Fisher, C. R.: Experimental evidence of habitat provision by aggregations of Riftia pachyptila at hydrothermal vents on the East Pacific Rise, Mar. Ecol., 28, 3-14, 2007.

Govenar, B., Le Bris, N., Gollner, S., Glanville, J., Aperghis, A. B., Hourdez, S., and Fisher, C. R.: Epifaunal community structure associated with Riftia pachyptila aggregations in chemically different hydrothermal vent habitats, Mar. Ecol.-Prog. Ser., 305, 67-77, 2005.

Govenar, B., Fisher, C. R., and Shank, T. M.: Variation in the diets of hydrothermal vent gastropods, Deep-Sea Res. Pt. II, 121, 193201, 2015.

Govenar, B. W., Bergquist, D. C., Urcuyo, I. A., Eckner, J. T., and Fisher, C. R.: Three Ridgeia piscesae assemblages from a single Juan de Fuca Ridge sulphide edifice: Structurally different and functionally similar, Cah. Biol. Mar., 43, 247-252, 2002.

Gray, J. S.: The measurement of marine species diversity, with an application to the benthic fauna of the Norwegian continental shelf, J. Exp. Mar. Bio. Ecol., 250, 23-49, 2000. 
Grelon, D., Morineaux, M., Desrosiers, G., and Juniper, K.: Feeding and territorial behavior of Paralvinella sulfincola, a polychaete worm at deep-sea hydrothermal vents of the Northeast Pacific Ocean, J. Exp. Mar. Bio. Ecol., 329, 174-186, 2006.

Harasewych, M. G. and Kantor, Y. I.: Buccinum thermophilum (Gastropoda: Neogastropoda: Buccinidae), a new species from the Endeavour vent field of the Juan de Fuca Ridge, J. Molluscan Stud., 68, 39-44, 2002.

Hügler, M. and Sievert, S. M.: Beyond the Calvin cycle: autotrophic carbon fixation in the ocean, Ann. Rev. Mar. Sci., 3, 261-289, 2011

Jones, C. G., Lawton, J. H., and Shachak, M.: Organisms as ecosystem engineers, in: Ecosystem management, Springer, New York, 69, 130-147, 1994.

Jones, C. G., Lawton, J. H., and Shachak, M.: Positive and negative effects of organisms as physical ecosystem engineers, Ecology, 78, 1946-1957, 1997.

Jones, M. L.: On the Vestimentifera, new phylum: six new species, and other taxa, from hydrothermal vents and elsewhere, Bull. Biol. Soc. Washingt., 6, 117-158, 1985.

Jumars, P. A., Dorgan, K. M., and Lindsay, S. M.: Diet of worms emended: an update of polychaete feeding guilds, Ann. Rev. Mar. Sci., 7, 497-520, 2015.

Kelley, D. S., Carbotte, S. M., Caress, D. W., Clague, D. A., Delaney, J. R., Gill, J. B., Hadaway, H., Holden, J. F., Hooft, E. E. E., Kellogg, J. P., Lilley, M. D., Stoermer, M., Toomey, D., Weekly, R., and Wilcock, W. S. D.: Endeavour Segment of the Juan de Fuca Ridge: one of the most remarkable places on earth, Oceanography, 25, 44-61, 2012.

Kelly, N. E. and Metaxas, A.: Influence of habitat on the reproductive biology of the deep-sea hydrothermal vent limpet Lepetodrilus fucensis (Vetigastropoda: Mollusca) from the Northeast Pacific, Mar. Biol., 151, 649-662, 2007.

Kornicker, L. S.: Myodocopid ostracoda of hydrothermal vents in the eastern Pacific Ocean, Smithson. Contrib. Zool., 516, 1-46, 1991.

Krantz, G. W.: A new species of Copidognathus Trouessart (Acari: Actinedida: Halacaridae) from the Galapagos Rift, Can. J. Zool., 60, 1728-1731, 1982.

Lee, R. W. and Childress, J. J.: Inorganic N assimilation and ammonium pools in a deep-sea mussel containing methanotrophic endosymbionts, Biol. Bull., 190, 373-384, 1996.

Lelièvre, Y., Legendre, P., Matabos, M., Mihály, S., Lee, R. W., Sarradin, P.-M., Arango, C. P., and Sarrazin, J.: Astronomical and atmospheric impacts on deep-sea hydrothermal vent invertebrates, Proc. R. Soc. B Biol. Sci., 284, 20162123, https://doi.org/10.1098/rspb.2016.2123, 2017.

Lelièvre, Y., Sarrazin, J., Marticorena, J., Schaal, G., Day, T., Legendre, P., Hourdez, S., and Matabos, M.: Grotto hydrothermal edifice: abundance and isotopic data from Ocean Networks Canada's Expedition 2015 and 2016, Wiring the Abyss, SEANOE, https://doi.org/10.17882/55008, 2018.

Lenihan, H. S., Mills, S. W., Mullineaux, L. S., Peterson, C. H., Fisher, C. R., and Micheli, F.: Biotic interactions at hydrothermal vents: Recruitment inhibition by the mussel Bathymodiolus thermophilus, Deep-Sea Res. Pt. I, 55, 1707-1717, 2008.

Levesque, C., Juniper, S. K., and Marcus, J.: Food resource partitioning and competition among alvinellid polychaetes of Juan de
Fuca Ridge hydrothermal vents, Mar. Ecol.-Prog. Ser., 246, 173182, 2003.

Levesque, C., Limén, H., and Juniper, S. K.: Origin, composition and nutritional quality of particulate matter at deep-sea hydrothermal vents on Axial Volcano, NE Pacific, Mar. Ecol.-Prog. Ser., 289, 43-52, 2005.

Levesque, C., Kim Juniper, S., and Limén, H.: Spatial organization of food webs along habitat gradients at deep-sea hydrothermal vents on Axial Volcano, Northeast Pacific, Deep. Res. Pt. I, 53, 726-739, 2006.

Levin, L. A. and Michener, R. H.: Isotopic evidence for chemosynthesis-based nutrition of macrobenthos: the lightness of being at Pacific methane seeps, Limnol. Oceanogr., 47, 13361345, 2002.

Levin, L. A., Mendoza, G. F., Konotchick, T., and Lee, R.: Macrobenthos community structure and trophic relationships within active and inactive Pacific hydrothermal sediments, Deep-Sea Res. Pt. II, 56, 1632-1648, 2009.

Levin, L. A., Ziebis, W., F. Mendoza, G., Bertics, V. J., Washington, T., Gonzalez, J., Thurber, A. R., Ebbe, B., and Lee, R. W.: Ecological release and niche partitioning under stress: Lessons from dorvilleid polychaetes in sulfidic sediments at methane seeps, Deep-Sea Res. Pt. II, 92, 214-233, 2013.

Limén, H., Levesque, C., and Juniper, K. S.: POM in macro/meiofaunal food webs associated with three flow regimes at deep-sea hydrothermal vents on Axial Volcano, Juan de Fuca Ridge, Mar. Biol., 153, 129-139, 2007.

Luther, G., Rozan, T., Taillefert, M., Nuzzio, D., Di Meo, C., Shank, T., Lutz, R., and Cary, C.: Chemical speciation drives hydrothermal vent ecology, Nature, 410, 813-816, 2001.

Maddocks, R. F. and Steineck, P. L.: Ostracoda from experimental wood-island habitats in the deep sea, Micropaleontology, 33, 318-355, 1987.

Marcus, J., Tunnicliffe, V., and Butterfield, D. A.: Post-eruption succession of macrofaunal communities at diffuse flow hydrothermal vents on Axial Volcano, Juan de Fuca Ridge, Northeast Pacific, Deep-Sea Res. Pt. II, 56, 1586-1598, 2009.

Martell, K. A., Tunnicliffe, V., and Macdonald, I. R.: Biological features of a buccinid whelk (Gastropoda, Neogastropoda) at the Endeavour vent fields of Juan de Fuca Ridge, northeast Pacific, J. Molluscan Stud., 68, 45-53, 2002.

Matabos, M., Plouviez, S., Hourdez, S., Desbruyères, D., Legendre, P., Warén, A., Jollivet, D., and Thiébaut, E.: Faunal changes and geographic crypticism indicate the occurrence of a biogeographic transition zone along the southern East Pacific Rise, J. Biogeogr., 38, 575-594, 2011.

Matabos, M., Cuvelier, D., Brouard, J., Shillito, B., Ravaux, J., Zbinden, M., Barthelemy, D., Sarradin, P.-M., and Sarrazin, J.: Behavioural study of two hydrothermal crustacean decapods: Mirocaris fortunata and Segonzacia mesatlantica, from the lucky strike vent field (mid-Atlantic Ridge), Deep-Sea Res. Pt. II, 121, 146-158, 2015.

McHugh, D. and Tunnicliffe, V.: Ecology and reproductive biology of the hydrothermal vent polychaete Amphisamytha galapagensis (Ampharetidae), Mar. Ecol.-Prog. Ser., 106, 111-120, 1994.

McLean, J. H.: New archaeogastropod limpets from hydrothermal vents; superfamily Lepetodrilacea I. Systematic descriptions, Philos. T. R. Soc. London B, 319, 1-32, 1988. 
McLean, J. H.: New slit-limpets (Scissurellacea and Fissurellacea) from hydrothermal vents, Contributions Sci. Hist. museum Los Angeles Cty, 1989.

Micheli, F., Peterson, C. H., Mullineaux, L. S., Fisher, C. R., Mills, S. W., Sancho, G., Johnson, G. A., and Lenihan, H. S.: Predation structures communities at deep-sea hydrothermal vents, Ecol. Monogr., 72, 365-382, 2002.

Michener, R. and Lajtha, K.: Stable isotopes in ecology and environmental science, Blackwell, Oxford, 2008.

Moalic, Y., Desbruyères, D., Duarte, C. M., Rozenfeld, A. F., Bachraty, C., and Arnaud-Haond, S.: Biogeography revisited with network theory: Retracing the history of hydrothermal vent communities, Syst. Biol., 61, 127-137, 2011.

Mullineaux, L. S., Fisher, C. R., Peterson, C. H., and Schaeffer, S. W.: Tubeworm succession at hydrothermal vents: use of biogenic cues to reduce habitat selection error?, Oecologia, 123, 275-284, 2000.

Mullineaux, L. S., Peterson, C. H., Micheli, F., and Mills, S. W.: Successional mechanism varies along a gradient in hydrothermal fluid flux at deep-sea vents, Ecol. Monogr., 73, 523-542, 2003.

Nedoncelle, K., Lartaud, F., de Rafelis, M., Boulila, S., and Le Bris, N.: A new method for high-resolution bivalve growth rate studies in hydrothermal environments, Mar. Biol., 160, 1427-1439, 2013.

Nedoncelle, K., Lartaud, F., Contreira-Pereira, L., Yücel, M., Thurnherr, A. M., Mullineaux, L., and Le Bris, N.: Bathymodiolus growth dynamics in relation to environmental fluctuations in vent habitats, Deep-Sea Res. Pt. I, 106, 183-193, 2015.

Newsome, S. D., del Rio, C. M., Bearhop, S., and Phillips, D. L.: A niche for isotopic ecology, Front. Ecol. Environ., 5, 429-436, 2007.

Oksanen, J., Blanchet, F. G., Friendly, M., Kindt, R., Legendre, P., Mcglinn, D., Minchin, P. R., O’hara, R. B., Simpson, G. L., Solymos, P., Henry, M., Stevens, H., Szoecs, E., and Wagner, H.: vegan: Community Ecology Package, R Packag. version 2.42, available at: https://CRAN.R-project.org/package=vegan, last access: September 2017.

Pettibone, M. H.: New genera and species of deep-sea Macellicephalinae and Harmothoinae (Polychaeta: Polynoidae) from the hydrothermal rift areas off the Galapagos and Western Mexico at $21^{\circ} \mathrm{N}$ and from the Santa Catalina Channel, Proc. Biol. Soc. Washingt., 98, 740-757, 1985.

Pettibone, M. H.: New species and new records of scaled polychaetes (Polychaeta: Polynoidae) from hydrothermal vents of the Northeast Pacific Explorer and Juan de Fuca Ridges, Proc. Biol. Soc. Washingt., 101, 192-208, 1988.

Portail, M., Olu, K., Dubois, S. F., Escobar-Briones, E., Gelinas, Y., Menot, L., and Sarrazin, J.: Food-web complexity in Guaymas Basin hydrothermal vents and cold seeps, PLoS One, 11, e0162263, https://doi.org/10.1371/journal.pone.0162263, 2016.

Ramirez-Llodra, E., Shank, T., and German, C.: Biodiversity and biogeography of hydrothermal vent species: thirty years of discovery and investigations, Oceanography, 20, 30-41, 2007.

Sancho, G., Fisher, C. R., Mills, S., Micheli, F., Johnson, G. A., Lenihan, H. S., Peterson, C. H., and Mullineaux, L. S.: Selective predation by the zoarcid fish Thermarces cerberus at hydrothermal vents, Deep-Sea Res. Pt. I, 52, 837-844, 2005.
Sarrazin, J. and Juniper, S. K.: Biological characteristics of a hydrothermal edifice mosaic community, Mar. Ecol.-Prog. Ser., 185, 1-19, 1999.

Sarrazin, J., Robigou, V., Juniper, S. K., and Delaney, J. R.: Biological and geological dynamics over four years on a hightemperature sulfide structure at the Juan de Fuca Ridge hydrothermal observatory, Mar. Ecol.-Prog. Ser., 153, 5-24, 1997.

Sarrazin, J., Juniper, S. K., Massoth, G., and Legendre, P.: Physical and chemical factors influencing species distributions on hydrothermal sulfide edifices of the Juan de Fuca Ridge, northeast Pacific, Mar. Ecol.-Prog. Ser., 190, 89-112, 1999.

Sarrazin, J., Levesque, C., Juniper, S. K., and Tivey, M. K.: Mosaic community dynamics on Juan de Fuca Ridge sulphide edifices: Substratum, temperature and implications for trophic structure, Cah. Biol. Mar., 43, 275-279, 2002.

Sarrazin, J., Cuvelier, D., Peton, L., Legendre, P., and Sarradin, P.M.: High-resolution dynamics of a deep-sea hydrothermal mussel assemblage monitored by the EMSO-Açores MoMAR observatory, Deep-Sea Res. Pt. I, 90, 62-75, 2014.

Sarrazin, J., Legendre, P., de Busserolles, F., Fabri, M. C., Guilini, K., Ivanenko, V. N., Morineaux, M., Vanreusel, A., and Sarradin, P. M.: Biodiversity patterns, environmental drivers and indicator species on a high-temperature hydrothermal edifice, MidAtlantic Ridge, Deep-Sea Res. Pt. II, 121, 177-192, 2015.

Scheltema, A. and Kuzirian, A. M.: Helicoradomenia juani gen. et sp. nov., a Pacific hydrothermal vent Aplacophora (Mollusca: Neomeniomorpha), The Veliger, 34, 195-203, 1991.

Shoemaker, C. R.: The amphipoda of the Cheticamp expedition of 1917, Contrib. to Can. Biol. Fish., 5, 219-359, 1930.

Soto, L. A.: Stable carbon and nitrogen isotopic signatures of fauna associated with the deep-sea hydrothermal vent system of Guaymas Basin, Gulf of California, Deep-Sea Res. Pt. II, 56, 16751682, 2009.

Southward, E. C., Tunnicliffe, V., and Black, M.: Revision of the species of Ridgeia from northeast Pacific hydrothermal vents, with a redescription of Ridgeia piscesae Jones (Pogonophora: Obturata = Vestimentifera), Can. J. Zool., 73, 282-295, 1995.

Stiller, J., Rousset, V., Pleijel, F., Chevaldonné, P., Vrijenhoek, R. C., and Rouse, G. W.: Phylogeny, biogeography and systematics of hydrothermal vent and methane seep Amphisamytha (Ampharetidae, Annelida), with descriptions of three new species, Syst. Biodivers., 11, 35-65, 2013.

Sweetman, A. K., Levin, L. A., Rapp, H. T., and Schander, C.: Faunal trophic structure at hydrothermal vents on the southern Mohn's Ridge, Arctic Ocean, Mar. Ecol.-Prog. Ser., 473, 115131, 2013.

Tanaka, H., Lelièvre, Y., and Yasuhara, M.: Molecular phylogeny and description of a new hydrothermal vent species of Xylocythere (Ostracoda) from the Juan de Fuca Ridge with a note on possible functions of pore clusters, Marine Biodiversity, submitted, 2018.

Tsurumi, M. and Tunnicliffe, V.: Characteristics of a hydrothermal vent assemblage on a volcanically active segment of Juan de Fuca Ridge, northeast Pacific, Can. J. Fish. Aquat. Sci., 58, 530-542, 2001.

Tsurumi, M. and Tunnicliffe, V.: Tubeworm-associated communities at hydrothermal vents on the Juan de Fuca Ridge, northeast Pacific, Deep-Sea Res. Pt. I, 50, 611-629, 2003. 
Tunnicliffe, V.: The biology of hydrothermal vents: ecology and evolution, Oceanogr. Mar. Biol. Annu. Rev., 29, 319-407, 1991.

Tunnicliffe, V. and Thomson, R.: The Endeavour hot vents area: a pilot Marine Protected Area in Canada's Pacific Ocean, Report for Fisheries and Oceans Canada, 1999.

Tunnicliffe, V., Desbruyères, D., Jollivet, D., and Laubier, L.: Systematic and ecological characteristics of Paralvinella sulfincola Desbruyères and Laubier, a new polychaete (family Alvinellidae) from northeast Pacific hydrothermal vents, Can. J. Zool., 71, 286-297, 1993.

Turnipseed, M., Knick, K. E., Lipcius, R. N., Dreyer, J., and Van Dover, C. L.: Diversity in mussel beds at deep-sea hydrothermal vents and cold seeps, Ecol. Lett., 6, 518-523, 2003.

Urcuyo, I., Massoth, G., Julian, D., and Fisher, C.: Habitat, growth and physiological ecology of a basaltic community of Ridgeia piscesae from the Juan de Fuca Ridge, Deep-Sea Res. Pt. I, 50, 763-780, 2003.

Urcuyo, I., Bergquist, D., MacDonald, I., VanHorn, M., and Fisher, C.: Growth and longevity of the tubeworm Ridgeia piscesae in the variable diffuse flow habitats of the Juan de Fuca Ridge, Mar. Ecol.-Prog. Ser., 344, 143-157, 2007.

Van Dover, C. L.: Trophic relationships among invertebrates at the Kairei hydrothermal vent field (Central Indian Ridge), Mar. Biol., 141, 761-772, 2002.

Van Dover, C. L.: Variation in community structure within hydrothermal vent mussel beds of the East Pacific Rise, Mar. Ecol.Prog. Ser., 253, 55-66, 2003.
Van Dover, C. L. and Fry, B.: Stable isotopic compositions of hydrothermal vent organisms, Mar. Biol., 102, 257-263, 1989.

Van Dover, C. L. and Fry, B.: Microorganisms as food resources at deep-sea hydrothermal vents, Limnol. Oceanogr., 39, 51-57, 1994.

Van Dover, C. L. and Trask, J. L.: Diversity at deep-sea hydrothermal vent and intertidal mussel beds, Mar. Ecol.-Prog. Ser., 195, 169-178, 2000.

Van Dover, C. L., German, C. R., Speer, K. G., Parson, L. M., and Vrijenhoek, R. C.: Evolution and biogeography of deep-sea vent and seep invertebrates, Science, 295, 1253-1257, 2002.

Warén, A. and Bouchet, P.: Four new species of Provanna Dall (Prosobranchia, Cerithiacea?) from East Pacific hydrothermal sites, Zool. Scr., 15, 157-164, 1986.

Warén, A. and Bouchet, P.: New gastropods from East Pacific hydrothermal vents, Zool. Scr., 18, 67-102, 1989.

Windoffer, R. and Giere, O.: Symbiosis of the hydrothermal vent gastropod Ifremeria nautilei (Provannidae) with endobacteriastructural analyses and ecological considerations, Biol. Bull., 193, 381-392, 1997.

Xu, G., Jackson, D. R., Bemis, K. G., and Rona, P. A.: Time-series measurement of hydrothermal heat flux at the Grotto mound, Endeavour Segment, Juan de Fuca Ridge, Earth Planet. Sc. Lett., 404, 220-231, 2014.

Zekely, J., Van Dover, C. L., Nemeschkal, H. L., and Bright, M.: Hydrothermal vent meiobenthos associated with mytilid mussel aggregations from the Mid-Atlantic Ridge and the East Pacific Rise, Deep-Sea Res. Pt. I, 53, 1363-1378, 2006. 